\title{
Structural Dislocations \\ in Eastern Massachusetts
}

G E O L O G I C A L S U R V E Y B U L L E T I N 144110

$8 E 75$
89
$n 0.1410$ 



\section{Structural Dislocations}

\section{- in Eastern Massachusetts}

By ROBERT O. CASTLE, H. ROBERTA DIXON, EDWARD S. GREW, ANDREW GRISCOM, and ISIDORE ZIETZ

GE O L O G I C A L S U R V E Y B U L LE T́ I N 14110

$A$ description of the major faults and mylonite zones that form the eastern Massachusetts dislocation belt

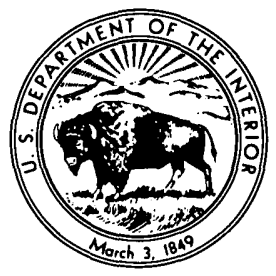




\section{UNITED STATES DEPARTMENT OF THE INTERIOR}

THOMAS S. KLEPPE, Secretary

\section{GEOLOGIGAL SURVEY}

V. E. McKelvey, Director

Library of Congress Cataloging in Publication Data

Main entry under title:

Structural dislocations in eastern Massachusetts.

(Geological Survey Bulletin 1410)

Bibliography: p.

Supt. of Docs. no.: I 19.3:1410

1. Faults (Geology)-Massachusetts. 2. Mylonite-Massachusetts.

I. Castle, Robert O. II. Series: United States Geological Survey Bulletin 1410.

QE75.B9 no. 1410 [QE606.5.U6] 557.3'08s [551.8'7] 76-608000

For sale by the Superintendent of Documents, U.S: Government Printing Office Washington, D. C. 20402

Stock Number 024-001-02852-2 


\section{CONTENTS}

Abstract fowan

\section{ILLUSTRATIONS}

Plate 1. Generalized geologic and aeromagnetic intensity map of part of eastern Massachusetts

In pocket

FigURE 1. Map of Massachusetts showing area described in this report ................. 3

2. Map showing major structural features in southeastern New England.. 4

3. Photomicrographs showing mylonitic fabrics of granitic rocks along the south side of the Essex fault

4. Photomicrographs showing characteristic fabrics developed in the Burlington mylonite zone 
TA.BLE

\section{TABLE}

Page

TABLE 1. Provisional correlation chart for units mapped within the eastern Massachusetts dislocation belt...

\section{CONVERSION TABLE}

$$
\begin{aligned}
& 1 \text { millimetre }=0.03937 \mathrm{inch} \\
& 1 \text { centimetre }=0.3937 \mathrm{inch} \\
& 1 \text { metre }=3.281 \mathrm{feet} \\
& 1 \text { kilometre }=0.6214 \mathrm{mile}
\end{aligned}
$$




\title{
STRUCTURAL DISLOCATIONS IN EASTERN MASSACHUSETTS
}

\author{
By Robert O. Castle, H. Roberta Dixon, Edward S. Grew, ${ }^{1}$ \\ ANDREW GrisCoM, and ISIDORE ZieTZ
}

\begin{abstract}
Geologic and geophysical investigations begun in the 1950's have identified a series of major structural dislocations associated with a highly deformed northeast-trending belt within the crystalline rocks of eastern Massachusetts. Although these dislocations, together with their extensions into Connecticut, form a translational zone extending more than $200 \mathrm{~km}$ across southeastern New England, their recognition is obscured by an extensive cover of glacial drift and by their coincidence in trend with the regional structural grain. The two chief dislocation zones are identified as the Essex fault system and the Burlington fault system.

The Essex fault is clearly recognized on the basis of geologic evidence along a 15$\mathrm{km}$ reach in northern Essex County; southwest of Lowell it is expressed as a profound discontinuity in magnetic intensity. The Essex fault can be traced southwestward from Newburyport at least as far as the Shrewsbury quadrangle, a distance of nearly 100 $\mathrm{km}$; magnetic evidence suggests that it extends south-southwestward an additional 30 $\mathrm{km}$. The Burlington fault system lies between the Essex fault and the Northern Boundary fault of the Boston basin. Recognition of the separate elements of this system, including the Burlington mylonite zone, the Bloody Bluff fault, and the Lake Char fault, has depended largely on the identification of mylonitic rocks associated with these dislocations. The Burlington mylonite zone is composed of rocks ranging from nearly ultramylonite through flaser gneiss and highly recrystallized blastomylonite; it can be traced for at least $55 \mathrm{~km}$. The Bloody Bluff fault is expressed both as finely laminated mylonite and as an abrupt break in magnetic intensity; it can be traced $30 \mathrm{~km}$ on the basis of geologic evidence alone. The Lake Char fault extends north and east from its type area near the Connecticut-Massachusetts state line at least as far as the Marlboro quadrangle; magnetic data permit eastward extension beyond the Marlboro area an additional 15-20 km. Evidence developed to date suggests that the Burlington system probably cannot extend eastward into the Atlantic and may be truncated by later block faulting.

The character and age of the displacements that accompanied the evolution of the eastern Massachusetts dislocation belt are very poorly known. Separations of thousands of metres can be demonstrated locally, but correlation of identifiable units across the major fault strands and the apparent termination of the system in southern Connecticut argue that displacements are nowhere measurable in tens of kilometres. Mylonitization probably began during late Precambrian time and persisted locally and probably discontinuously into the Ordovician. Discrete faulting was reinstituted along the primordial dislocation zones perhaps as late as Permian time; we have no direct evidence, however, of major translational movements associated with Acadian (Devonian) orogenesis.
\end{abstract}

'Department of Geology, University of California, Los Angeles, California 90024 


\section{INTRODUCTION}

Although geologic reports published before the late 1950's identify a number of isolated, seemingly unrelated fault segments within the area between the Connecticut Valley and the Boston and Narragansett basins of eastern Massachusetts and Rhode Island (Crosby, 1899; Emerson, 1917, pl. X; Clapp, 1921, pl. 1; Foye, 1949, p. 88; Sclar, 1950), it was not until detailed geologic and geophysical studies were begun in the 1950's that the regional significance of several of these faults began to be appreciated. Recognition of this significance, however, has evolved very slowly. The existence of even the greatest of these dislocations is almost completely obscured by both the extensive glacial cover and the parallelism and coincidence between many of these breaks and the regional structural grain, especially as it is defined by formational boundaries. Adding to this obscurity, moreover, is the fact that many of these dislocations are expressed as broad, nebulously defined mylonite or shear zones-zones, in effect, of extreme attenuation separating blocks that have otherwise maintained their structural integrity.

This report synthesizes what is now known of the structural dislocations identified or reasonably inferred within a highly deformed belt extending northeastward from the Massachusetts-Rhode Island-Connecticut junction to the mouth of the Merrimack River (fig. 1), and extends into Massachusetts the major fault synthesis developed for eastern Connecticut (fig. 2) by Dixon and Lundgren (1968). The described belt is naturally bounded on the north and northwest by the southern limit of the Merrimack Group of Billings (1956), a boundary that coincides in part with the east-northeast-trending reach of the Merrimack River; it is similarly bounded on the southeast by the Northern Boundary fault of the Boston basìin (fig. 2). Although we recognize evidence for faulting in eastern Massachusetts outside of this belt, particularly to the southeast (Billings, 1929; LaForge, 1932), the chief faults between the Connecticut Valley and the Boston basin (fig. 2) probably are confined largely to the area outlined in figure 1 .

The detailed synthesis presented here (pl. 1) has been developed chiefly from two sources: (1) Such published and unpublished public documents describing the geology within and adjacent to this belt as had become known to us by December 31, 1973; and (2) published 71/2-minute aeromagnetic quadrangle maps of Massachusetts. These data have been supplemented locally through ground reconnaissance by the writers. Only about one-third of this area (pl. 1) has been mapped in detail (at scales of 1:31,680, 1:24,000, or larger), but much of this mapping has been in structurally critical localities. Probably the greatest handicap we face 


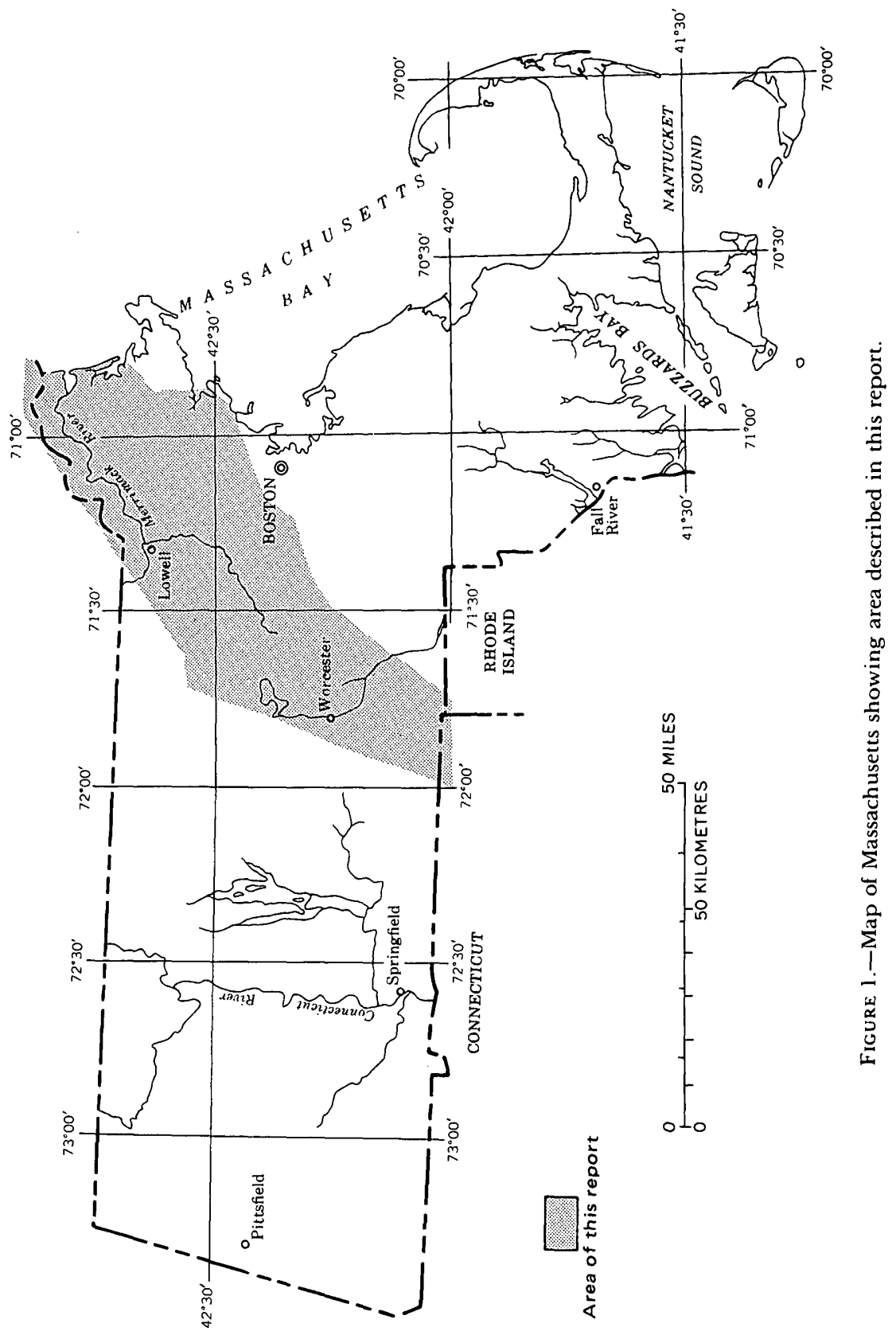


in understanding the structural configuration of this belt stems from our limited knowledge of the regional stratigraphy, a limitation that derives in turn from the very few diagnostic fossils discovered in this part of New England. While radiometric dates have contributed in some measure in fixing the ages of these rocks, they are partly equivocal and are generally useful in establishing no more than the minimum ages of plutons that are commonly much younger than the rocks they intrude. Because the geologic ages, as well as the relative ages, of many of the units mapped within the area of plate 1 are in doubt, the correlation chart prepared for this report (table 1) should be viewed as no more than tentative.

The identification of major throughgoing faults within the crystalline rocks of southeastern New England dates from at least as early as 1958 with the discovery by Lundgren, Goldsmith, and Snyder (1958) of the

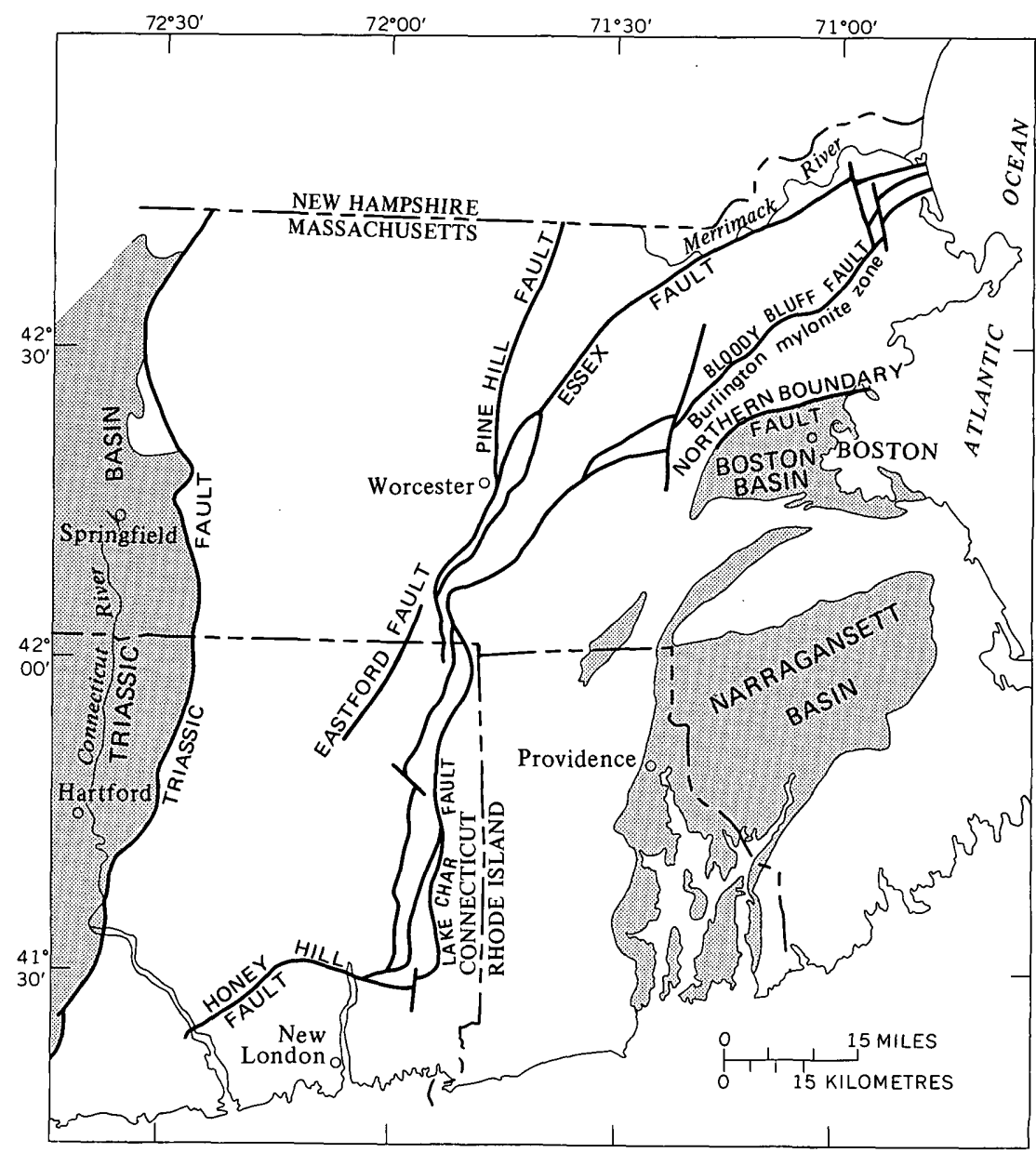

Figure 2.-Major structural features in southeastern New England. 
Honey Hill fault in eastern Connecticut (fig. 2). Later mapping, moreover, has shown that the Honey Hill turns sharply to the north near the Rhode Island border, where it joins the Lake Char fault (fig. 2) and strikes northward into Massachusetts (Dixon and Lundgren, 1968). The Lake Char fault in turn is apparently continuous with one or the other of two major dislocations in northeastern Massachusetts first described by Cuppels (1961) and Castle (1964; 1965a; 1965b; 1966). The probable connection between the Connecticut and Massachusetts parts of this extended fault belt was first suggested by J. L. Rosenfeld (1962, oral commun.); Skehan's (1967; 1968) studies of the Wachusett-Marlborough Tunnel, midway between the Connecticut border and northeastern Massachusetts, seemed to confirm this suggestion. Mapping by Novotny (1961) and Grew (1970) in Massachusetts and by Pease and Peper (1968) in northeastern Connecticut has identified the Pine Hill and Eastford faults (fig. 2), respectively, either or both of which may be major branches of the southeastern New England fault belt discussed in this report. Thus it is properly inferred from this brief synopsis that we have relied heavily on the mapping of these and other earlier workers in developing the synthesis presented here (pl. l).

\section{AEROMAGNETIC DATA}

The total intensity aeromagnetic map (pl. l) was compiled from 41 separately published $7 \frac{1}{2}$-minute aeromagnetic quadrangle maps of the U.S. Geological Survey. The data were collected along east-west traverses spaced at $0.8-\mathrm{km}$ intervals and flown at $150 \mathrm{~m}$ above ground level. Although the contour interval used here is 100 gammas, the 1:24,000-scale source maps from which this map was prepared were drawn with a 20 gamma contour interval. The magnetic overlay differs in addition from the original maps in that the regional magnetic gradient has been removed through subtraction of the earth's main field (International Geomagnetic Reference Field-1965 of Fabiano and Peddie, 1969).

The magnetic anomalies shown on plate 1 stem chiefly from differences in magnetite content among individual rock masses; variations in magnetite content are functions in turn of both initial composition and metamorphic grade. Because remanent magnetization rarely is quantitatively significant in plutonic or metamorphic rocks, rock magnetization in this area is thought to be chiefly induced. Hence, in interpreting these anomalies we have assumed that they are the products of induced magnetization only. Moreover, in areas of relatively steep magnetic inclination such as this, boundaries between magnetic units are located at or near the points of inflection (or zero second derivative) of the observed magnetic gradients (Vacquier and others, 1951). The rock units that generate these anomalies (pl. 1) crop out at the surface; thus where magnetic boundaries and independently recognized geologic contacts coincide, these contacts can be extended into areas of poor exposure 
TABLE 1.-Provisional correlation for units mapped

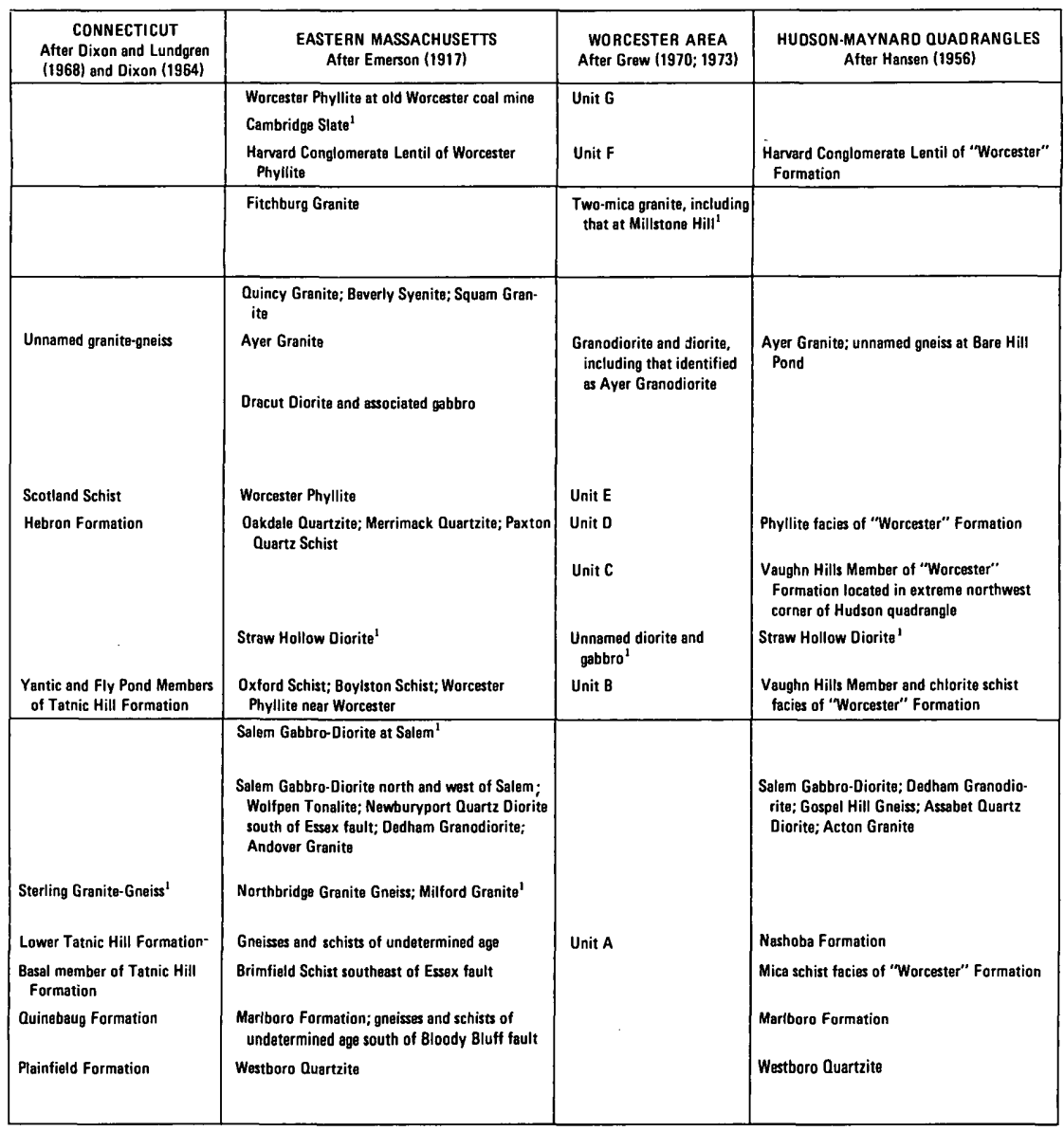

${ }^{1}$ Relative age uncertain

${ }^{2}$ Mylonitic facies of the Marlboro and perhaps other formations

${ }^{3} \mathrm{Geologic}$ ages of many units uncertain and subject to revision

simply on the basis of the magnetic data. Several of the plutons shown on plate 1 , for example, are characterized by sufficiently simple magnetic expression that geologic boundaries can be reliably mapped from the magnetic data alone. Heterogeneous or metamorphosed rock units, on the other hand, tend to vary in their magnetic properties such that magnetic boundaries associated with these rocks are less apt to coincide with otherwise established geologic contacts. In any case, the magnetic data generally provide geometric constraints on inferred geologic contacts; they usually offer little or no guidance, however, concerning the nature of these contacts. Sharply truncated magnetic lineaments can, nevertheless, provide virtually compelling evidence of faulting; there exists a similar, although lesser likelihood that relatively long and linear magnetic boundaries may also coincide with faults. 
within the eastern Massachusetts dislocation belt

\begin{tabular}{|c|c|c|c|c|}
\hline $\begin{array}{c}\text { BOSTON BASIN } \\
\text { After Laforge (1932) }\end{array}$ & $\begin{array}{l}\text { LAWRENCE-SALEM AREA } \\
\text { After Castle (1964; 1965a; 1965b) } \\
\text { and Toulmin (1964) }\end{array}$ & $\begin{array}{l}\text { NEWBURYPORT AREA } \\
\text { After Shride (1971), Billings } \\
\text { (1956), and Clapp (1921) }\end{array}$ & THIS REPORT & $A G E^{3}$ \\
\hline Cambridga Slate & & & $\begin{array}{l}\text { Unit G of Grew } \\
\text { Cambridge Slate' } \\
\text { Harvard Conglomerate }\end{array}$ & $\begin{array}{l}\text { Pennsylvanian } \\
\text { Carboniferous } \\
\text { Pennsylvanian }\end{array}$ \\
\hline Lynn Volcanic Complex & Newbury Formation & Newbury Formation & $\begin{array}{l}\text { Fitchburg Granite } \\
\text { Newbury Formation; Lynn } \\
\text { Volcanic Complex }\end{array}$ & $\begin{array}{l}\text { Devonian(?) } \\
\text { Silurian and } \\
\text { Devonian } \\
\end{array}$ \\
\hline Quincy Granite & $\begin{array}{l}\text { Granitic rocks of the "alkalic" } \\
\text { intrusive series } \\
\text { Dracut Diorite } \\
\text { Merrimack Group } \\
\text { Worcester(?) Phyllite }\end{array}$ & $\begin{array}{l}\text { Newburyport Quartz } \\
\text { Diorite north of Essex } \\
\text { fault } \\
\text { Merrimack Group }\end{array}$ & $\begin{array}{l}\text { Granitic rocks of the "alkat } \\
\text { lic" intrusive series } \\
\text { Ayer Granite } \\
\text { Oracut Diorite } \\
\text { Newburyport Quartz } \\
\text { Oiorite } \\
\text { Worcester Phyllite } \\
\text { Merrimack Group; Paxton } \\
\text { Quartz Schist } \\
\text { Unit C of Graw } \\
\text { Straw Hollow Diorite' } \\
\text { Boylston Schist }\end{array}$ & $\begin{array}{l}\text { Ordovician } \\
\text { Ordovician } \\
\text { Ordovician } \\
\text { Ordovician } \\
\text { Ordovician or older } \\
\text { Ordovician or older } \\
\text { Ordovician or older } \\
\text { Ordovician or older } \\
\text { Ordovician or older }\end{array}$ \\
\hline Salem Gabbro-Diorite at Salem ${ }^{\prime}$ & $\begin{array}{l}\text { Selem Gabbro-Diorita } \\
\text { Unnamed serpentinite' }\end{array}$ & & $\begin{array}{l}\text { Salem Gabbro-Diorite }{ }^{1} \\
\text { Unnamed serpentinite }\end{array}$ & $\begin{array}{l}\text { Ordovician or older } \\
\text { Ordovician of older }\end{array}$ \\
\hline $\begin{array}{l}\text { Salem Gabtro-Diorite west of } \\
\text { Salem; Newburyport Quartz } \\
\text { Diorite; Dedham Granodio. } \\
\text { rite; Andover Granite }\end{array}$ & $\begin{array}{l}\text { Nashoba Formation } \\
\text { Brimfield-type schist }\end{array}$ & $\begin{array}{l}\text { Unnamed pink quartz mon- } \\
\text { zonite and fine-grainad } \\
\text { diorite; Newburyport } \\
\text { Quartz Diorite south of } \\
\text { Essex fault }\end{array}$ & $\begin{array}{l}\text { Calcalkalic rocks of the } \\
\text { subalkaline intrusive } \\
\text { series } \\
\text { Northbridge Granite Gneiss; } \\
\text { Milford Granite' } \\
\text { Nashoba Formation } \\
\text { Brimfield-type schist }\end{array}$ & $\begin{array}{l}\text { Precambrian(?) } \\
\text { Precambrian(?) } \\
\text { Precambrian(?) }\end{array}$ \\
\hline $\begin{array}{l}\text { Marlboro Formation; Woburn } \\
\text { Formation }{ }^{2} \text {; Waltham Gneiss } \\
\text { Westboro Quartzite }\end{array}$ & $\begin{array}{l}\text { Marlboro Formation; Boxford Forma- } \\
\text { tion } \\
\text { Westboro-type quartzite } \\
\text { Fish Brook Gneiss }\end{array}$ & $\begin{array}{l}\text { Unnamed metamorphic } \\
\text { rocks }\end{array}$ & $\begin{array}{l}\text { Marlboro Formation } \\
\text { Westboro Quartzite } \\
\text { Fish Brook Gneiss }\end{array}$ & $\begin{array}{l}\text { Pracambrian } \\
\text { Precambrian } \\
\text { Precambrian }\end{array}$ \\
\hline
\end{tabular}

In areas identified with irregular magnetic patterns the contoured data may offer little direct information concerning the locations of geologic contacts. These data may, nonetheless, place helpful constraints on the probable locations of these contacts. Geologic boundaries cannot generally, for example, be expected to transect magnetic lineament's, except perhaps where large magnetic dikes are known to cut across the regional grain.

In areas of relatively simple magnetic expression, it is sometimes possible to approximate the dip of a magnetic boundary from the width and form of the magnetic gradient. A computer-generated atlas of magnetic profiles characterized by planar contacts has been used here to estimate dips of magnetic boundaries that correspond with either geologically or geophysically inferred faults. These dips are considered accurate to within $\pm 10^{\circ}$. 
The magnetic data developed within the area of our study (pl. 1) were interpreted chiefly through evaluation of the 71/2-minute aeromagnetic source maps and comparisons of these data with available geologic information. Because the aeromagnetic overlay shown on plate 1 lacks the detail of the $71 / 2$-minute aeromagnetic quadrangle maps, it is not always clear from inspection of the overlay why a particular interpretation has been adopted without at the same time examining the $7 \frac{1}{2}$-minute source maps. Where the flight-line spacing is the same or greater than the spacing between adjacent magnetic highs paralleling the flight directions, ambiguities arose locally in correlating anomalies between flight lines, especially where the geologic trends form small angles with these lines. Inconsistencies with geologic information, moreover, have in several places led us to recontour the flight-line data on the $7 \frac{1}{2}$-minute maps; when this was done it has usually been indicated in the text. Although ambiguities in the magnetic data generally are minor in this area, there are several places, such as the center of the Ipswich quadrangle (pl. 1), where an equally convincing alternative contour map could have been prepared on the basis of the existing aeromagnetic data. Finally, in those few places where modern geologic mapping clearly conflicts with the boundaries deduced from the magnetic data, and the cause of the discrepancy has not been determined, the geologically based interpretation is shown.

\section{MAJOR FAULT SYSTEMS}

Major dislocations projecting across eastern Massachusetts include: (1) The Essex fault system; (2) the Burlington fault system; and.(3) the Northern Boundary fault of the Boston basin.

\section{THE ESSEX FAULT SYSTEM}

The Essex fault system is characterized by a single well-defined break, the Essex fault (pl. 1), over most of its eastern, on-land extent. Southwestward toward Connecticut this system is expressed as a series of distributed and less clearly defined faults, including the Essex, Clinton, and various unnamed branches and secondary ruptures (pl. 1).

\section{ESSEX FAULT}

The name Essex fault is given here to the regionally developed, eastnortheast-trending dislocation whose existence is most clearly demonstrated in northern Essex County, Massachusetts (pl. 1). This fault characteristically separates the Merrimack Group on the north and west from a Precambrian(?) and generally much more highly metamorphosed terrane on the south and east; it is identical over most of its recognized extent with an unnamed, major dislocation identified by Castle (1964, p. 521-522, fig. 22; 1965a, p. C76; 1965b, p. C82; 1966) and subsequently characterized by Skehan (1968, p. 281-283) as the Clinton-Newbury fault. Its extreme eastern on-land position near Newburyport coincides 
approximately with the Scotland Road fault (Shride, 1971, p. 108, 113), first recognized by Clapp (1921, pl. 1) but restricted by him to the area east of long $71^{\circ} \mathrm{W}$. Southwest of the Ayer quadrangle the Essex fault splits into a complex of subparallel faults (pl. 1), and it is uncertain which of these is the major break. The continued use of the name "Clinton-Newbury" for this fault is considered inappropriate for several reasons: (1) Its projected position lies 3-4 km north of the center of Newbury, barely within the town limits. (2) The main trace of this fault probably coincides with what Skehan (1968, p. 282-287) identifies as the Rattlesnake Hill fault and, hence, lies east of the town of Clinton. (3) Whether the Essex fault coincides in part with Skehan's (1968, p. 282-287) Clinton fault (pl. l) is an open question; it is almost certainly not continuous, however, with his type Clinton-Newbury fault, located immediately north of the north portal of the Wachusett-Marlborough Tunnel and about $1 \mathrm{~km}$ northwest of the Clinton fault (pl. 1). (4) The Essex fault is explicitly defined by a variety of criteria in northern Essex County, whereas evidence of the regional significance of this feature is much more equivocal southwestward toward Clinton. The name "Scotland Road" is considered nearly as inappropriate chiefly because published evidence of the existence of this fault is much less compelling along Scotland Road (Shride, 1971, p. 113-115) than it is immediately west of this area.

Although a part of what we show here as the main trace of the Essex fault in the Clinton quadrangle ( $\mathrm{pl} . \mathrm{l}$ ) was first recognized by Crosby (1899, p. 87-96), his mapping was confined to the general area of the Wachusett Aqueduct tunnel; hence, the regional significance of this dislocation (Skehan's Rattlesnake Hill fault) remained unrecognized by Crosby. Crosby (1899, p. 95-96), moreover, rejected the likelihood that the gneissic fabric of the granite abutting the fault was an imposed structure generated in association with movement on the Essex fault; he concluded instead that the gneissic nature of this rock was "due to the drag of the stiffly viscous granite magma along its walls during its intrusion into the [adjacent] schist and diorite." Regional investigations carried out concurrently and at least partly subsequent to Crosby's studies, convinced Emerson (1917, p. 77-78) that "even though these rocks [included on plate 1 chiefly with the Boylston Schist and Brimfield-type schist] are much more metamorphosed, every effort to find boundaries separating them from the less altered rocks [included on plate 1 with the Worcester Phyllite and the Merrimack Group]* * *in the Worcester area has failed." He went on to say that "I began the study of the rocks around Worcester with a prejudice in favor of such boundaries and for a long time I urged. my assistants to find them, but at last I gave up the quest." A third of a century later detailed studies in this same general area led R. H. Jahns, L. W. Currier, M. E. Willard, and W. R. Hansen to nearly the identical conclusion (Hansen, 1956, p. 20). Hansen (1956, p. 20), in fact, defined a new unit, the Worcester Formation (to include both the Worcester Phyllite and 
Figure 3.-Mylonitic fabrics in the granitic rocks along the south side of the Essex fautt: $\mathrm{M}$, microcline; $\mathrm{P}$, plagioclase; $\mathrm{Q}$, quartz. $A$, Muscovite granite-gneiss facies of the Andover Granite exposed $450 \mathrm{~m} \mathrm{~N} .68^{\circ} \mathrm{E}$. of the Mt. Vernon-Beacon Street intersection, Lawrence (Lawrence quadrangle); crossed nicols. $B$, Adamellite exposed 1250 $\mathrm{m} \mathrm{S}$. $12^{\circ} \mathrm{W}$. of the Salem Street-Washington Street intersection, Groveland (South Groveland quadrangle); crossed nicols.

the easterly parts of the Brimfield Schist of previous reports), that actually lies athwart what we show here as the Essex fault. (See Hansen, 1956, pl. 1.) We stress this history to show that what is now recognized as a major regional dislocation is so thoroughly obscured by the apparently conformable relations at least as far northeast as Lowell, that it simply escaped detection by a number of highly trained observers.

The existence of the Essex fault is clearly documented in the Lawrence and South Groveland quadrangles (pl. 1). Evidence for its occurrence in this area consists of: (1) Stratigraphic topping of the Merrimack Group toward the southeast against rocks that almost certainly predate the entire Merrimack Group; (2) locally intense mylonitization or cataclasis of granitic rocks that crop out against the postulated position of this fault (fig. 3); (3) a sharp break in metamorphic rank from sillimanite zone on the south to biotite and chlorite zone on the north; (4) a discontinuity in the pattern of intrusion and the nature of the intrusive rocks along the fault trace; and (5) truncation against the fault trace of structural trends developed on both sides of the fault (Castle, 1964, p. 521, fig. 22, pl. 1; $1965 \mathrm{~b} ; 1966$, p. 197). Because this fault is clearly defined in the South Groveland and Lawrence quadrangles, and because all but perhaps the first and the last of the above listed criteria are now known to occur, with local discontinuity, between the Lawrence and Clinton quadrangles (See also, U.S. Geological Survey, 1970p, p. A22), the Essex fault can be projected on the basis of geologic evidence alone at least as far southwest as the Clinton quadrangle (pl. l). The aeromagnetic data, moreover, neatly corroborate the occurrence of a major fault along this reach. As shown both on plate 1 and even more strikingly on the 20-gamma contour quadrangle maps (U.S. Geological Survey, 1970b; 1970e; 1970f; 197la; 1971b; 1971d; 1971f), a major boundary between units of sharply contrasting magnetic properties closely coincides with the Essex fault between the Lawrence and Clinton quadrangles. The clearly diminished aspect of this magnetic boundary through and east of the Lawrence quadrangle, where the Essex fault is especially well defined on geologic grounds, probably is due chiefly to the interruption of the intensely magnetic Nashoba Formation by the weakly magnetic rocks of the subalkaline intrusive series (pl. 1), specifically, the Andover Granite (Castle, 1965a, p. C76). Thus, there exists far less magnetic contrast (although by no means no magnetic contrast) between the rocks along both sides of the fault east of the western part of the Lawrence quadrangle. 


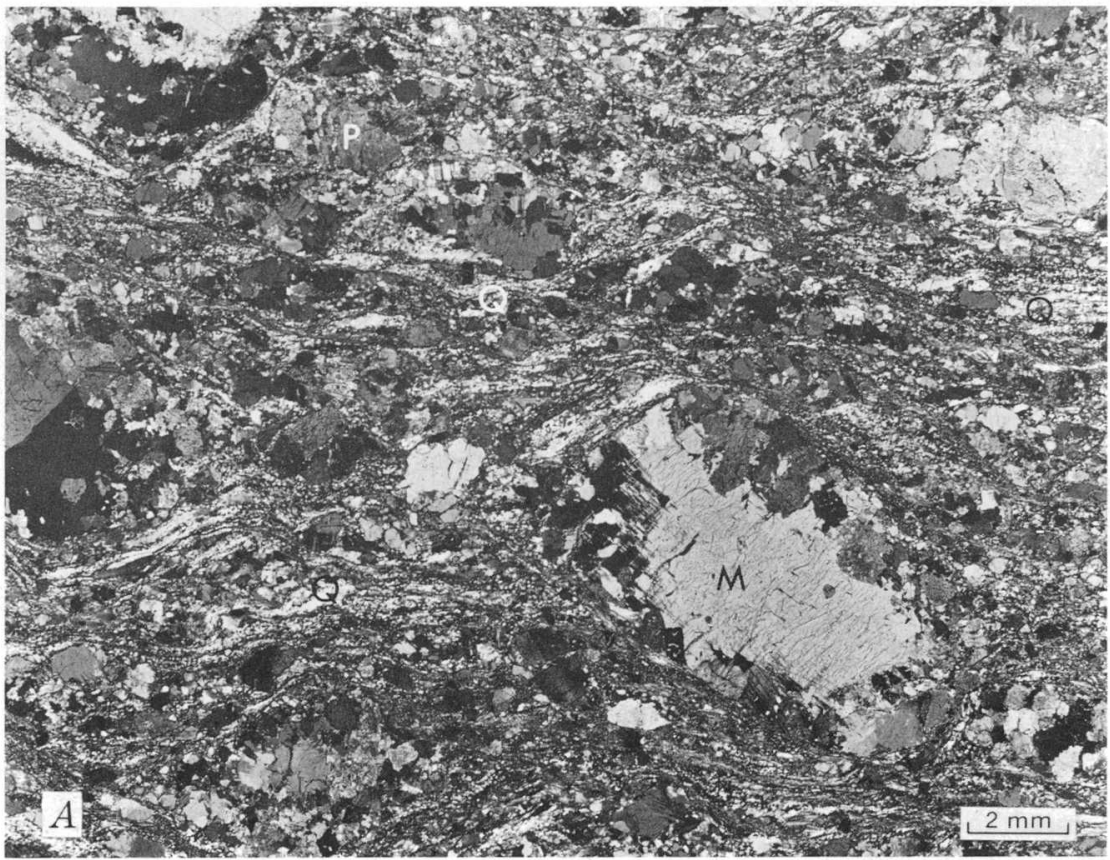
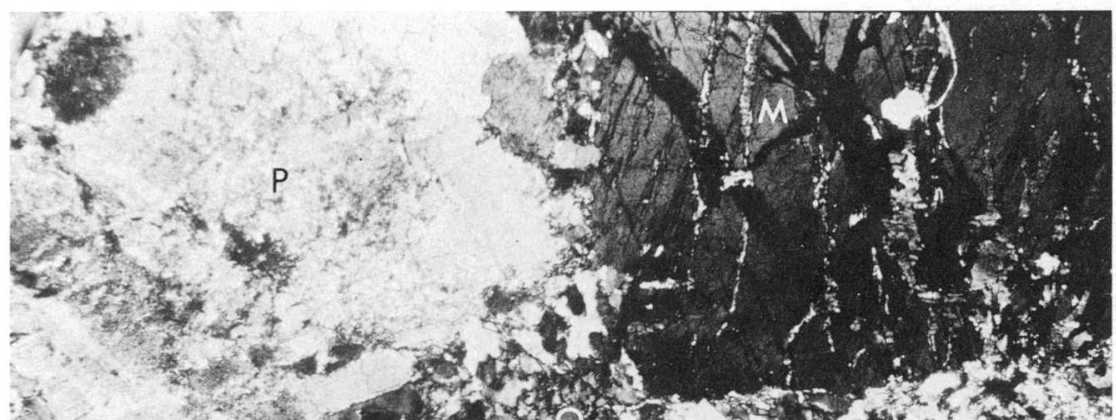

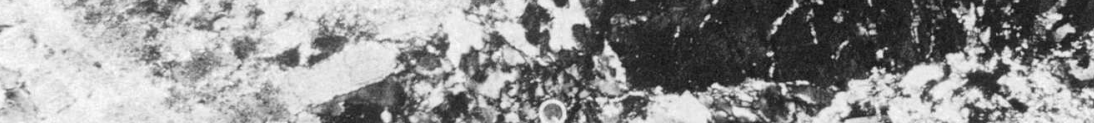

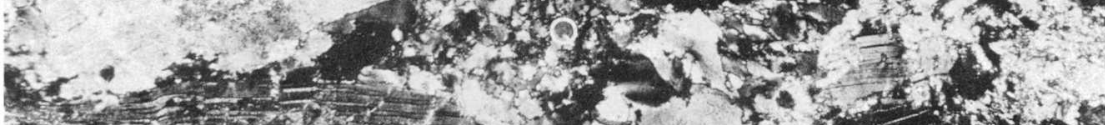

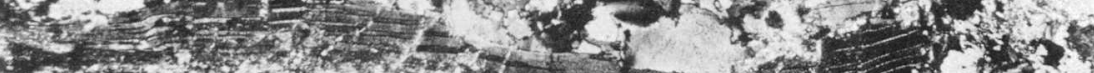
S.

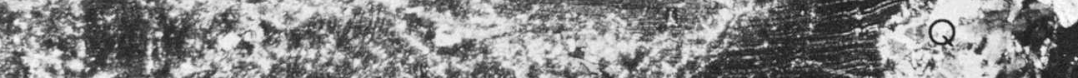
S.4.

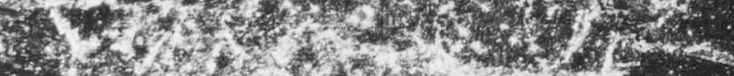

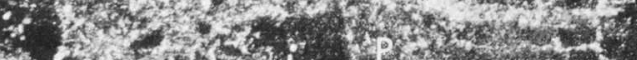

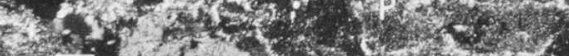
$B^{3}, 25-5$
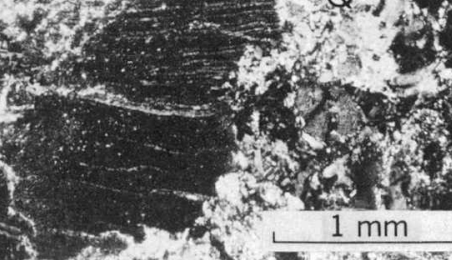

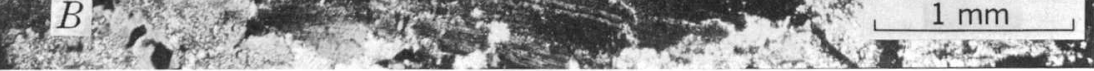


Geologic criteria suggesting extension of the Essex fault east of the South Groveland and southwest of the Clinton quadrangles are in part conflicting. Hence in these areas we have relied heavily on the magnetic data shown on the detailed 71/2-minute-aeromagnetic quadrangle maps.

Existing information derived from both geologic and geophysical observations suggests that the Essex fault probably extends out to sea and into the Gulf of Maine south of the New Hampshire border. Thus, accumulating evidence indicates both that the Newburyport Quartz Diorite intrudes the Merrimack Group (Novotny, 1969; M. P. Billings, 1970, written commun.), and that it belongs to the same plutonic series as do the Dracut Diorite and Ayer Granite (Zartman and Naylor, 1972). It is increasingly likely on the basis of radiometric data, moreover, that this series is Ordovician in age (Zartman and Naylor, 1972), in spite of the fact that a good case can be made from field evidence that the Merrimack Group is itself no older than Silurian (Billings, 1956, p. 99-105). Because Shride $(1971$, p. 106, 113) has shown that rocks characteristic of this unnamed Ordovician plutonic series in the Newburyport area are restricted to the area north of the Essex fault (his Scotland Road fault), and because calcalkalic intrusive rocks of Ordovician age are not known to occure south of the Essex fault (although the Andover Granite has been radiometrically dated as Ordovician by Handford (1965, p. 14), this is probably a minimum age), it is likely that Shride's Scotland Road fault defines the eastward projection of the Essex fault (pl. 1). This interpretation is supported by the detailed aeromagnetic data shown on the 71/2minute quadrangle maps (U.S. Geological Survey, 1970j; 1970k). These same data, however, coupled with relatively tight geologic control in the South Groveland and Haverhill quadrangles, argue that the Essex fault is itself offset in the southwest corner of the Newburyport West quadrangle (pl. 1).

Southwest of the Hudson quadrangle the Essex fault apparently splits into several separate strands. The main trace of this fault probably follows the course shown on plate 1 and is thus coincident with Skehan's (1968, p. 282-287) Rattlesnake Hill fault; alternatively, it may curve sharply westward along the trace of the Clinton fault (pl. 1). Neither of these suggested alternatives seems wholly satisfactory. If the main trace of the Essex fault coincides with the Clinton fault, it permits the occurrence of Ayer Granite southeast of this trace; yet northeast of the Clinton quadrangle the Ayer Granite is restricted to the area northwest of the Essex fault. If, on the other hand, the Essex fault projects southwestward as shown on plate 1 , it uniquely isolates a large mass of the Nashoba Formation northwest of the fault. This apparently anomalous situation is conceivably explained by the possibility that the Essex fault actually terminates against the Lake Char fault in either the Webster or Oxford quadrangles, and that rocks identified with the Nashoba west of this postulated location of the Essex fault (pl. 1), while lithologically similar, 
are improperly correlated with the Nashoba Formation. For example, a persistent sequence contained within what is represented here as Nashoba Formation and Boylston Schist in southern Massachusetts and northern Connecticut (pl. 1) does not appear within the Nashoba Formation in the type area. Accordingly, because the Nashoba Formation shown as cropping out west of the Essex fault in the Shrewsbury and Worcester South quadrangles (pl. 1) probably is continuous with units included provisionally with the Nashoba in southern Massachusetts and northern Connecticut (table 1), the Nashoba Formation, contrary to what we show here (pl. 1), may not occur west of the Essex fault. In any case, because the structural feature projected into the Shrewsbury quadrangle as the Essex fault ( $\mathrm{pl} . \mathrm{l}$ ) is characterized by the same relatively smooth trend and steep dip (see below) as is the segment extending northeastward, and because there is no clear stratigraphic or otherwise independent basis for choosing between these two alternatives, our choice here has been governed chiefly by geometric considerations.

Extension of the Essex fault southward from the central part of the Shrewsbury quadrangle derives almost entirely from interpretation of the aeromagnetic data and is based only in small part on permissive geologic evidence. Furthermore, positive evidence supporting the existence of the east-northeast trending fault shown as offsetting the Essex fault in the central part of the Shrewsbury quadrangle is limited to truncation of an otherwise persistent and pronounced magnetic lineament that parallels the Brimfield-type schist for at least $20 \mathrm{~km}$ (pl. 1). Because bedrock control in the central Shrewsbury quadrangle is particularly poor, it is conceivable that the Brimfield-type schist may not be cut out but simply highly attenuated along the line of this geophysically inferred cross fault.

Dips on the primary dislocation surface have been measured directly at only two, nearly coincident points along the Essex fault (Crosby, 1899, p. 90-91; Skehan, 1968, p. 284), where they are recorded as steep and to the west-northwest (pl. 1). Steep dips along that part of the fault extending northeastward from the central part of the Shrewsbury quadrangle to at least the South Groveland quadrangle are suggested both by the relatively straight trace (U.S. Geological Survey, 1970p, p. A22) and dips of as much as $60^{\circ}$ or more measured on mylonitic rocks adjacent to the trace (pl. 1). Dips calculated from the magnetic gradients, moreover, are equally steep (pl. 1); there is no basis, however, magnetic or otherwise, for concluding that the Essex fault may continue northeastward beyond Lowell "at a much lower angle" (U.S. Geological Survey, 1970p, p. A22).

\section{OTHER FAULTS}

The Clinton fault (pl. 1) is recognized as the chief branch of the Essex fault system; it is clearly identified in tunnel exposures in the southern part of the Clinton quadrangle (Crosby, 1899, p. 89-90; Skehan, 1968, p. 284-287). Grew (1970, p. 215, 220-221) has since extended this dislocation 
into the Shrewsbury and Worcester North quadrangles. The occurrence of the Clinton fault in the Shrewsbury quadrangle is shown by discordance of structural trends and juxtaposition of sillimanite-zone rocks on the east against biotite-zone rocks on the west; its presence in the Worcester North quadrangle is defined by the occurrence of rocks of the Merrimack Group (mapped with the Oakdale Quartzite) structurally overlying the fossil-bearing Pennsylvanian unit $G$ of Grew (1973). We interpret the similarly positioned contact separating the Merrimack Group from the Boylston Schist in the Worcester South quadrangle (pl. 1) as the probable southerly projection of the Clinton fault. The Clinton fault, unlike the Essex, is characterized by relatively shallow dips averaging about $30^{\circ}$ northwest and ranging down to as low as $7^{\circ}$ northwest (Crosby, 1899, p. 90; Skehan, 1968, p. 284, 287; Grew, 1970, p. 221).

The fault shown as paralleling and branching off the main trace of the Essex fault along the southern flank of the Brimfield-type schist projecting southwestward from the Lawrence quadrangle (pl. 1), is inferred wholly from interpretation of the aeromagnetic data (U.S. Geological Survey, 1970e; 1970f, 1971 b; 1971d; 1971f). It is defined both by an abrupt change in magnetic intensity and by the truncation of a series of northeastward-trending magnetic lineaments that characterize the adjacent Nashoba Formation (pl. 1). Northeastward as far as the southcentral part of the Lowell quadrangle the magnetic contact along which we extend this fault dips steeply to the northwest, clearly mimicking the spatial configuration of the adjacent Essex fault. The magnetic data neither support nor refute extension of the fault eastward into the Lawrence quadrangle; hence the projection of this discontinuity eastward to its junction with the Essex fault (pl. 1) is, of necessity, hased on geologic considerations. Because the contact between the Brimfield-type schist and the subalkaline intrusive series lies along a nearly straight-line projection of this inferred fault, it seems impossibly fortuitous that it could be an intrusive contact and there is almost no likelihood that the Brimfield-type schist is in normal contact with the subalkaline intrusive series. Southwestward from the central part of the Lowell quadrangle the contact between the Brimfield-type schist and the Nashoba Formation could be an unconformity rather than a fault; it is very doubtful, however, in view of the angular relation between these two units (pl. 1) that "a reasonable case for an important disconformity can be made" (U.S. Geological Survey, 1971g, p. A19). Interpretation of this contact as any type of unconformity is questioned on two additional counts: (1) It seems unlikely that its linear expression (pl. 1) could have been preserved through the intense folding to which this sequence has been subjected. (2) Interpretation of the angular relation between the Nashoba Formation and the Brimfield-type schist (pl. 1) as an unconformity conflicts directly with the structural interpretation of Hansen (1956, p. 51-53), who cites evidence suggesting that the Nashoba Formation occupies the center of a 
broad snyclinorium and hence overlies the Brimfield-type schist, rather than vice versa. The southwestward extension of this postulated fault into the Hudson or even the Ayer quadrangles is conjectural. Hansen (1956, p. 26-32; 1972, written commun.) concludes from detailed studies of the contact between the Nashoba Formation and the Brimfield-type schist in the Hudson and Ayer quadrangles that it is both normal and gradational; thus even if this fault actually persists southwestward as far as we show (pl. 1), it is probably characterized by small displacements and must almost precisely parallel the planar lithic boundaries developed along its most southwesterly extension.

\section{THE BURLINGTON FAULT SYSTEM}

The series of dislocations that characterize the southeastern half of the map area north of the Northern Boundary fault (pl. 1) cannot be identified with a single, relatively simple break, such as the Essex fault. These spatially disconnected breaks, instead, seem to form a complex, genetically related system that we have named the Burlington fault system after one of its chief components. The Burlington fault system currently is recognized as consisting of: (1) The Burlington mylonite zone; (2) the Bloody Bluff fault of Cuppels (1961) and Skehan (1968); (3) the Lake Char fault of Dixon and Lundgren (1968); and (4) other unnamed, lesser dislocations.

\section{BURLINGTON MYLONITE ZONE}

The name Burlington mylonite zone is given here to the mylonite belt exposed in the town of Burlington (pl. 1) (Castle, 1964, p. 58-86, pl. 1, fig. $22 ; 1966)$. Although locally this belt is nearly $5 \mathrm{~km}$ wide, much of this width is the product of structural repetition attributable to later folding and faulting. Thus in the Lexington, Wilmington, and Reading quadrangles, for example, the mylonite zone is expressed as a gently northeasterly plunging antiform (Castle, 1964, p. 517-519, fig. 22) in which the actual thickness is probably no more than about $1.5 \mathrm{~km}$. Rocks included with the Burlington mylonite zone are identified chiefly with the Marlboro Formation. Locally, however, these mylonites are compositionally indistinguishable from rocks assigned to the subalkaline intrusive series. Thus even though this mylonite zone seems to be irregularly truncated by the subalkaline rocks (pl. 1), particularly the diorites (Castle, 1964, pl. 1, fig. 22), these rocks need not have actually intruded the mylonites. Mafic plutonic rocks, for whatever reason, may be relatively insusceptible to mylonitization (Higgins, 1971, p. 35), and the mylonitization may simply have been refracted around many of the larger diorite bodies.

The Burlington mylonite zone shows several megascopic features characteristic of classic mylonites. Many of the more leucocratic, siliceous rocks within the Burlington zone display the thin, very regular, varvelike layering of the typical hartschiefer, particularly along the 
edges of the main belt where it passes through the Reading, Wilmington, Lexington, Concord, and Framingham quadrangles. Still another locally developed megascopic feature characteristic of mylonitic rocks is the lensing in and out of various lithologies on all scales. Parenthetically, many of these rocks display uncommonly regular compositional layering that in no way precludes a mylonitic origin nor argues for a primary, bedded origin for these structures. (See, for example, Hsu, 1955, p. 340343; Christie, 1963, p. 428-429).

Microscopic examination firmly identifies the mylonitic origins of the Burlington belt. The porphyroclasts, almost without exception, consist of smoothly rounded individual crystals rather than lithic fragments. They are, in addition, composed chiefly of twinned feldspar (fig. 4) and in no case of quartz, hence refuting the notion that the clasts are arenaceous features or, nearly as unlikely, recrystallized amygdules. Many of the porphyroclasts are fractured or bent, and some are so broken up that the separate pieces are difficult to distinguish as parts of originally continuous grains (Castle, 1964, p. 84). The quartz fabrics are equally indicative of mylonitization; the quartz-rich mylonites are characterized both by ultra fine grained recrystallization or neomineralization textures and equally classic, ribbonlike fluxion structure (fig. $4, C$ and $D$ ).

Southeastward across the strike in the Wilmington quadrangle the rocks of the Burlington mylonite zone pass from very fine-grained, thinly laminated mylonites near the northern edge of the zone through relatively coarse augen or flaser gneisses (fig. $4 B$ ) near the center (along the approximate axial trace of the main fold), and thence back into fine-grained mylonitic quartz schists (fig. $4 C$ ) along the south flank of the zone. Mapping to date supports extension of the Burlington mylonite zone eastward to the western edge of the Salem quadrangle (Castle, 1964, fig. 22) and southwestward to the northeast corner of the Framingham quadrangle. Reconnaissance in the Lexington quadrangle, moreover, has shown that units mapped by LaForge (1932, p. 16-18, pl. 1) as the Waltham Gneiss and Woburn Formation are, in fact, zones of mylonite or blastomylonite rather than properly discriminated formations. Similarly, rocks mapped in the Concord quadrangle as laminated felsite (fig. $4 D$ ), thin-bedded paragneiss, quartz-hornblende-plagioclase schist, and at least parts of various other members identified with the Marlboro Formation (Cuppels, 1964, p. 83) are characterized by fabrics ranging from virtually ultramylonitic to flaser gneiss.

Re-examination of the augen gneiss mapped with unit B of the Marlboro Formation in the Salem quadrangle (Toulmin, 1964, p. A7-A8, pl. 1) shows that it is at least partly mylonitic or blastomylonitic (fig. $4 A$ ). As shown on plate 1 , this belt curves around to a northwesterly trend and is seemingly cut out against a small calcalkalic pluton in the northwest corner of the quadrangle. Northeastward from the Salem quadrangle we have identified several small areas of mylonite outcrops (pl. 1), but even 
together they hardly form a belt comparable with that in the Burlington area. The only evidence, in fact, supporting extension of the Burlington mylonite zone northeastward beyond the Salem quadrangle is the seeming correspondence between the magnetic lineaments so conspicuously developed in the Ipswich quadrangle and those that characterize the mylonites in the type area. Magnetic expression in the Burlington zone, however, probably is due chiefly to the amphibolitic rocks common to the Marlboro Formation (and may have been enhanced by the formation of magnetite during mylonitization), whereas reconnaissance in the Ipswich quadrangle shows that these magnetic lineaments are developed in a plutonic terrane characterized by massive, poorly foliated rocks. Hence, while the source of the magnetic pattern in the Ipswich quadrangle remains unknown, it is certainly clear that rock type need not be uniquely defined by magnetic expression. In the Ipswich quadrangle, moreover, the basic aeromagnetic data (U.S. Geological Survey, 19701) can be recontoured in such a way that these lineaments are substantially subdued. Such evidence as currently exists, accordingly, suggests that the Burlington mylonite zone probably does not extend seaward into the Gulf of Maine but simply turns northward and is cut out against or dips beneath the weakly magnetic rocks of the subalkaline intrusive series and Newbury Formation in the Salem and Georgetown quadrangles.

Southwestward from the Concord quadrangle the Burlington mylonite belt is less well known. Reconnaissance along strike from the Concord quadrangle has revealed several mylonite zones (pl. 1), but their development is sharply limited southwest of the Framingham quadrangle. Mylonitic appearing rocks mapped with the Marlboro Formation in the Marlboro and western half of the Framingham quadrangles are poorly exposed and, as viewed microscopically, are characterized by fabrics that seem to have lost the ultra fine grained mosaic textures that typify quartzose mylonites. In any case, whether or not the Burlington mylonite zone persists southwest of the Marlboro quadrangle as a discrete feature is certainly conjectural. Should it extend as far as the Oxford quadrangle, its occurrence elsewhere suggests that it should include only those mylonitic rocks cropping out northwest of the Lake Char fault.

The probable significance of the Burlington mylonites (or classic mylonites in general) as indices of major crustal dislocations deserves at least passing consideration. The recent work of Carter, Christie, and Griggs (1964), Theodore (1966; 1967), and Shelley (1971) suggests that mylonitic fabrics may evolve through simple flattening. Thus the mere existence of mylonite can no longer be taken as prima facie evidence of translation or shear. Nevertheless, the well defined spatial association between mylonites and major faults (See, for example, Higgins, 1971) and the restricted occurrence of most mylonites to relatively narrow belts within otherwise unmylonitized terranes argue that their extensive development is an indication of differential movement between bordering 

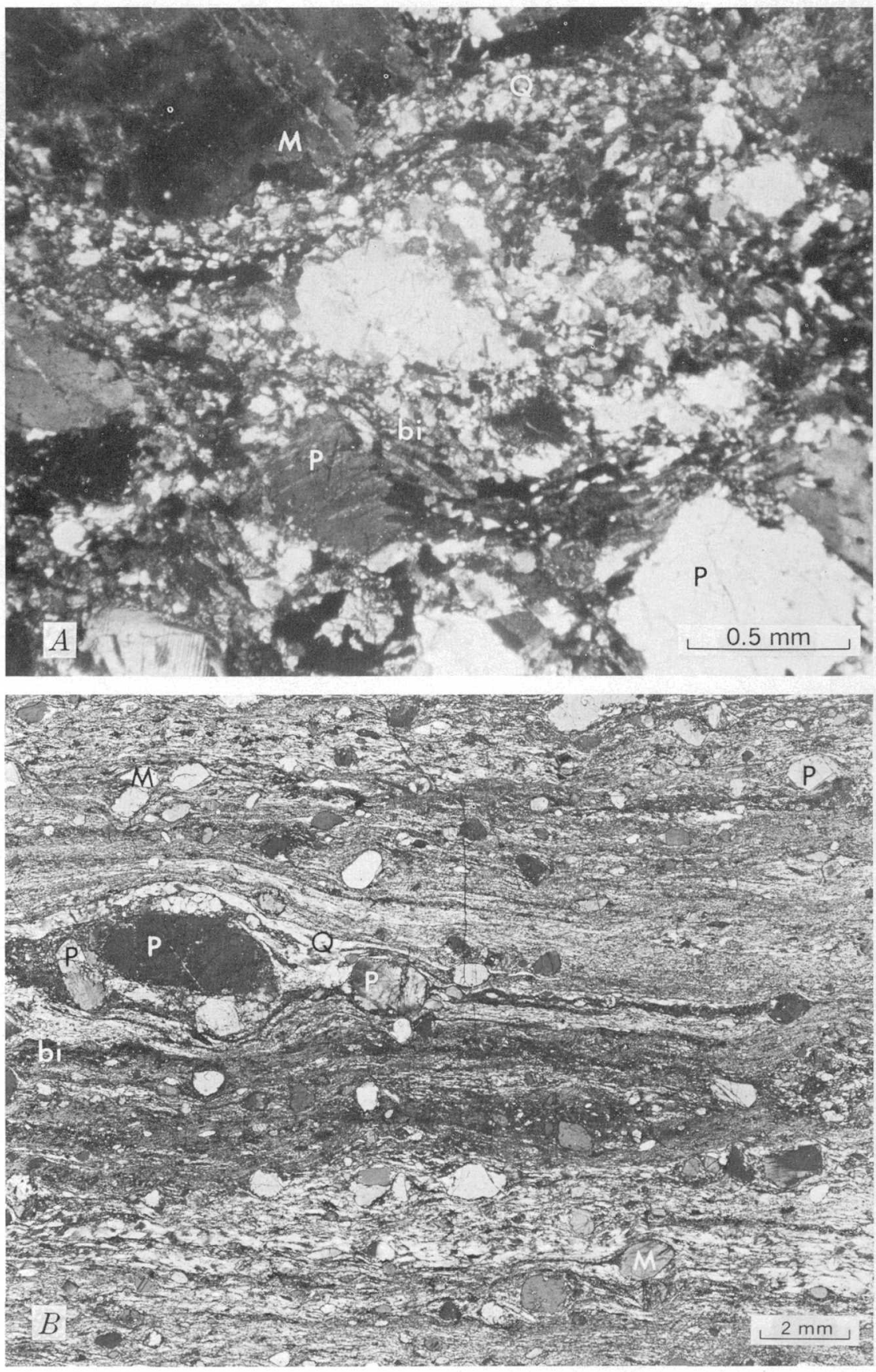

FiguRE 4.-Characteristic fabrics developed in the Burlington mylonite zone. F, feldspar; $\mathrm{M}$, microcline; $\mathrm{P}$, plagioclase; $\mathrm{Q}$, quartz; bi, biotite. $A$, Mylonitic augen gneiss from the Marlboro Formation exposed along Andover Street, $200 \mathrm{~m}$ northwest of the Newburyport Turnpike, Danvers (Salem quadrangle); crossed nicols. B, Porphyroclastic mylonite from the Marlboro Formation exposed along Main Street, $450 \mathrm{~m}$ south of Eames Street, Wilmington (Wilmington quadrangle); crossed nicols. C, Quartzose 

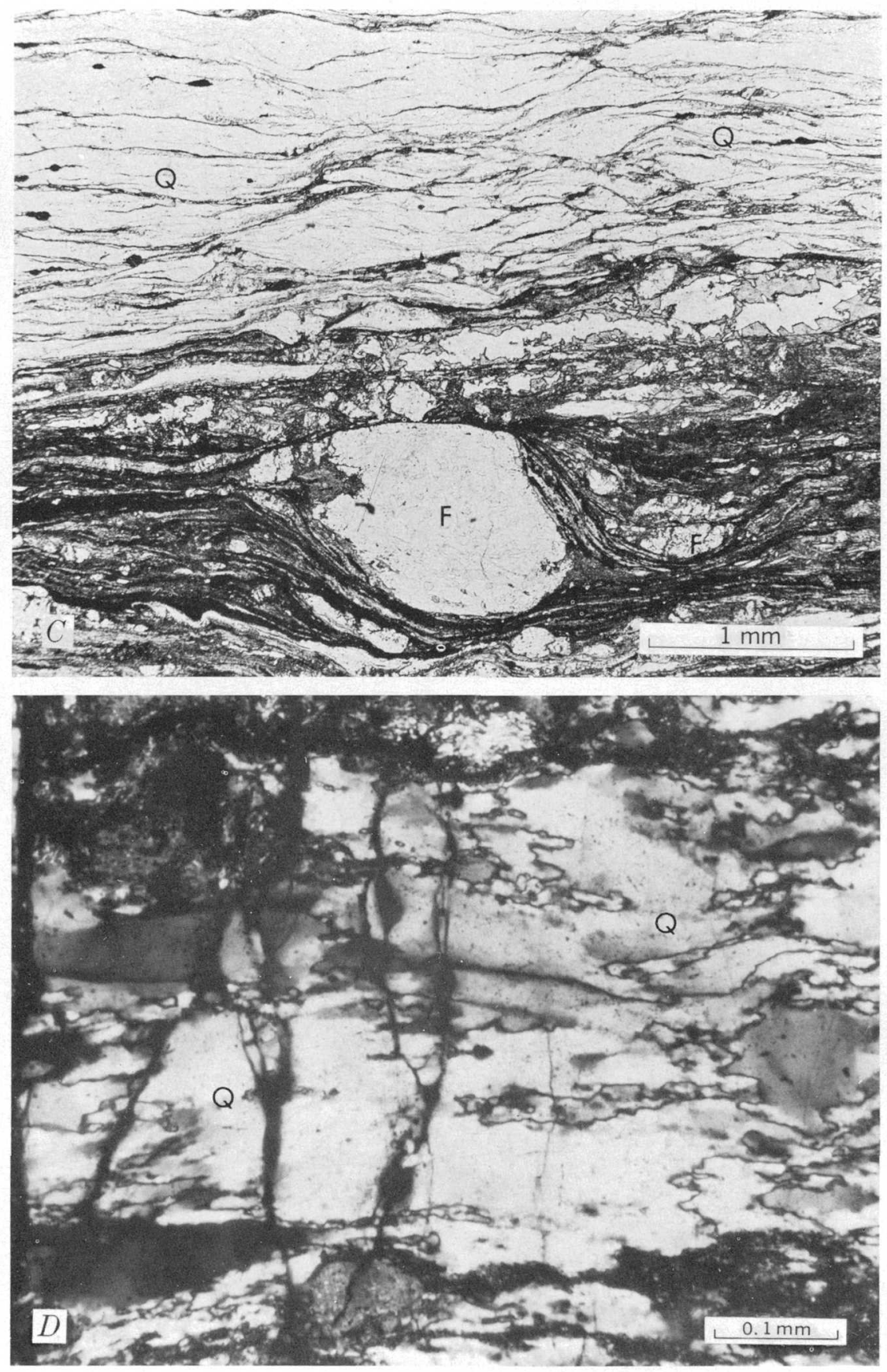

mylonite from the Marlboro Formation exposed along route 128, $750 \mathrm{~m}$ west of Mishawum Road, Woburn (Wilmington quadrangle); plane light. $D$, Mylonite from the Marlboro Formation exposed $350 \mathrm{~m} \mathrm{S.} 25^{\circ} \mathrm{W}$. of the Trapelo Road-Silver Hill Road intersection, Lincoln, and adjacent to the Bloody Bluff fault (Concord quadrangle); crossed nicols. 
crustal blocks. Because many of the mylonites in this area are associated with otherwise identifiable faults, we accept the likelihood that all of the locally occurring mylonites provide independent evidence of translation between crustal blocks-that is, faulting.

The small serpentinite body, composed chiefly of antigorite, cropping out in the Reading quadrangle along the south flank of the Burlington mylonite zone (pl. l), is doubly unique in that it is the only such body for tens of kilometres and is the only New England serpentinite known to us that shows such a close spatial relation to a recognized mylonite zone. Because serpentinites commonly are associated with major crustal dislocations, the coincidence between this serpentinite and the Burlington mylonite zone seems more than fortuitous.

\section{BLOODY BLUFF FAULT}

The name "Bloody Bluff" was first applied, at least informally, to a fault exposed at Bloody Bluff, near the east edge of the Concord quadrangle (Cuppels, 1961, p. D46). Skehan (1968, p. 283) subsequently identified as the "Bloody Bluff fault" a regional dislocation more than $80 \mathrm{~km}$ long and apparently continuous with the fault recognized initially by Cuppels. The map position of this fault as given by Skehan (1968, p. 283), however, is highly generalized over most of its extent and differs significantly from what we show here (pl. l) as the location of the main trace of the Bloody Bluff fault.

Cuppels (1961, p. D46) recognized "two major faults 35 feet [10.5 m] apart" within the Bloody Bluff exposures, which apparently consist chiefly of diorite in various stages of alteration and deformation. He listed the following criteria as evidence of a regionally significant fault: (1) severe shattering; (2) alteration of the constituent diorite materials; (3) offsets of lithologic units on minor fault surfaces ranging up to at least a metre or so; (4) crushed rock cropping out along the trend of what he identified as a major fault; and (5) hematite coatings on fracture surfaces. Probably the best geologic evidence, however, for the existence of a major dislocation approximately coincident with Cuppels' (1961) Bloody Bluff fault is the occurrence of a well-defined, thinly layered mylonite about 0.4 $\mathrm{km}$ east of Bloody Bluff. This mylonite equates roughly with Cuppels' (1964, p. 83, 86) "laminated felsite" unit and probably forms the main fault zone associated with the Bloody Bluff fault. On Plate 1 we identify the northwest margin of this unit as the "Bloody Bluff fault." Hence, within the Concord and nearby quadrangles the Bloody Bluff fault is shown as coinciding with the northern edge of the Burlington mylonite zone, and we suggest that what Cuppels (1961) characterized as the Bloody Bluff fault is, in fact, a relatively minor feature roughly paralleling the regional dislocation immediately southeast of Bloody Bluff.

Corroborative, and in many ways the best, evidence for the existence of the Bloody Bluff fault is in the aeromagnetic data. Thus, a line roughly 
coincident with this fault (pl. l) is described both by a major discontinuity in magnetic intensity and by conspicuously truncated magnetic lineaments that show up especially well on the detailed $71 \frac{1}{2}$ minute aeromagnetic quadrangle maps (U.S. Geological Survey, 1970c; $1970 \mathrm{~m} ; 1970 \mathrm{o})$. The correspondence between the geologically defined fault and the magnetically identified discontinuity is locally excellent. This near coincidence is shown exceptionally well, for example, in the central part of the Concord quadrangle. The coincidence breaks down, however, toward the northeast. Along the east margin of the Reading quadrangle the geologic criteria permit little more than a guess as to the most likely location of the fault, and the magnetic contact is equally vague. Our location of the Bloody Bluff fault southwest of the Concord quadrangle (pl. 1) is based entirely on the existence of a spatially consistent and very conspicuous aeromagnetic contact (the thinly laminated mylonite cropping out in the Maynard and Framingham quadrangles probably provides a southern limit on the location of this fault).

The geologically inferred position of the Bloody Bluff fault lies consistently northwest of the corresponding magnetic boundary. In the southern part of the Wilmington quadrangle, where the coincidence between these two features is very nearly at its best, the magnetic break lies no more than about two hundred metres southeast of the inferred location of the fault (Castle, 1964, fig. 22; U.S. Geological Survey, 1970o). In other areas, however, such as along the western margin of the Reading quadrangle, where both the fault and the magnetic contact are sharply defined, the magnetic boundary is as much as $1 \mathrm{~km}$ or more south of what we identify as the northern edge of the Burlington mylonite zone (Castle, 1964, fig. 22; U.S. Geological Survey, 1970m). This changing correspondence may correlate with magnetite oxidation in the northern part of the Burlington mylonite zone. Cuppels (1961, p. D46), for example, has reported hematite coatings on fracture surfaces in exposures at Bloody Bluff, and Castle (1964, p. 56) has identified specular hematite in the mylonitic rocks cropping out along the northern edge of the Burlington mylonite zone. Hematite does not generally occur, or is certainly inconspicuous elsewhere among the rocks of the Burlington mylonite zone.

The aeromagnetic data suggest that the southwestward extension of the Bloody Bluff fault terminates against (or coalesces with) a more southerly, essentially en echelon dislocation (the Lake Char) contained within the same fault system (pl. 1). The northeastward projection of the Bloody Bluff fault beyond the Reading quadrangle remains conjectural. Its trace is nearly east-west through the central part of the Reading quadrangle, but its position and trend east of there are both uncertain. The most likely interpretation ( $\mathrm{pl} . \mathrm{l}$ ) is that the fault turns northeastward along the east edge of the Reading quadrangle and through the northwest corner of the 
Salem quadrangle, that its dip shallows with this changing trend, and that it forms the structural base beneath the Newbury Formation in the Salem quadrangle. This interpretation, although consistent with geologic information, derives almost entirely from the aeromagnetic data (U.S. Geological Survey, 1970d; 1970m; 1970n): the line along which we extend this fault could be identified just as reasonably as an unconformity, at least within the Salem quadrangle.

The preceding interpretation demands that the Bloody Bluff fault finally terminate against a nearly parallel fault that Toulmin (1964, pl. 1) identifies with the northwestern contact of the Newbury Formation cropping out in the Salem quadrangle. This truncating fault, in turn, probably curves around to an almost southerly trend in the Reading quadrangle, where if forms the western boundary of a tiny, isolated sliver of the Newbury Formation (pl. 1). Its magnetic expression is shown clearly in the Reading quadrangle (U.S. Geological Survey, 1970m); this expression disappears, however, as the fault is traced northeastward into the Salem quadrangle (U.S. Geological Survey, 1970n), and it seems to transect a gentle but well-defined magnetic gradient recognized in the Georgetown quadrangle (pl. 1). Neither the aeromagnetic data nor what is known of the geologic relations permit extension of this offsetting fault southward beyond the northern boundary of the "alkalic" pluton cropping out in the southeast quarter of the Reading quadrangle. All of these considerations indicate that the unnamed subparallel fault is a much less significant feature than the Bloody Bluff fault and is almost certainly separable from the Bloody Bluff as mapped to the southwest.

The Bloody Bluff fault, as inferred from measurements on adjacent mylonites within and immediately northeastward from the type area, dips to the northwest at angles of $50^{\circ}-85^{\circ}(\mathrm{pl} .1)$. Dips calculated from the aeromagnetic data are generally consistent with those determined from the inclinations of the adjacent mylonitic rocks (pl. 1). The magnetically determined dips, however, suggest that the attitude of the Bloody Bluff fault shallows conspicuously to $20^{\circ}$ or less as it turns easterly and thence northerly across the Reading quadrangle.

\section{LAKE CHAR FAULT}

The Lake Char fault was named by Dixon and Lundgren (1968, p. 225) for its occurrence near Lake Chargoggagoggmanchauggagoggchaubunagungamaugg in southern Massachusetts. We adhere in this report, with some misgiving, to the short-hand Lake "Char" identification adopted by Dixon and Lundgren (1968, p. 225). The occurrence of the Lake Char fault is particularly well defined east of the northtrending Quinebaug River in Connecticut, where it is generally parallel or subparallel to the structural grain (Dixon and Lundgren, 1968, p. 225-226). Where it has been mapped in Connecticut, the Lake Char fault is everywhere associated with a conspicuous cataclastic zone as much 
as $750 \mathrm{~m}$ thick; the mylonitic and blastomylonitic rocks that characterize this zone, unlike those associated with the Bloody Bluff, are much more extensively developed in the upper (west) than the lower plate (Dixon and Lundgren, 1968, p. 225-226).

There is little doubt that the Lake Char fault extends northward into Massachusetts beyond. Lake Chargoggagoggmanchauggagoggchaubunagungamaugg; its location northeast of this area, however, is based on reconnaissance along its inferred trend ( $\mathrm{pl}$. 1), certain general but limiting regional considerations, and interpretation of the 1:24,000 aeromagnetic quadrangle maps (U.S. Geological Survey, 1968a; 1968b; 1969a; 1969b; 1969c; 1969e; 1970c; 1971c; 197le). Mapping in eastern Connecticut (Dixon and Lundgren, 1968, p. 222-223) shows that the Lake Char fault coincides with the contact between the Quinebaug (Marlboro equivalent) and Plainfield (Westboro equivalent) Formations. This contact, together with associated planar structures, turns northwestward at about the Connecticut-Massachusetts state line (pl. 1). Its extension northward as a fault is supported by the occurrence of mylonite outcrops and local concentrations of mylonitic rocks distributed through the glacial drift along the line of contact. Stone fences erected near the northern edge of the Oxford quadrangle, for example, consist largely of almost classic mylonitic rocks. Northeastward from the Oxford quadrangle to the middle of the Marlboro quadrangle the line along which we project the Lake Char fault coincides approximately with the northern contact against which the Westboro Quartzite cuts in and out along strike. Because this contact must be either an unconformity or a fault, and because a correspondingly positioned contact can be positively identified as a major fault in northern Connecticut, it seems likely that this Massachusetts analogue is also a fault. This likelihood is supported by the occurrence of mylonitic rocks along the inferred northeastward trace of the Lake Char fault, particularly in the upper plate (pl. 1).

Northward from Connecticut outcrops are sparse, and positioning of the Lake Char fault (that is, the precise location of the northern contact of the Westboro Quartzite) is governed largely by the aeromagnetic data. Although we have relied heavily on the magnetic data in attempting to define as precisely as possible the location of the Lake Char fault in Massachusetts, we recognize that these data may be misleading locally. Thus, immediately south of the Massachusetts line, where the fault can be located on the ground to within a few tens of metres, it lies about $0.5 \mathrm{~km}$ east of the corresponding magnetic contact (U.S. Geological Survey, 1971e).

Eastward from the center of the Marlboro quadrangle the mapped location of the Lake Char fault is based almost entirely on interpretation of the aeromagnetic data. The only geologic evidence supporting eastward extension of the Lake Char fault beyond the Marlboro quadrangle 
consists of sheared granitic rocks cropping out locally along its inferred trace (pl. 1). It is in this area, moreover, that the magnetic data are particularly difficult to reconcile with earlier geologic interpretations, owing largely to the geologic complexity and locally limited exposure. Hence, even though we recognize the inadequacy of such a procedure, where the magnetic data can be reasonably interpreted in several ways, we have generally accepted the interpretation that most closely approximates the earlier representation.

A. E. Nelson (U.S. Geological Survey, 1970p, p. A19) has reported two major faults in the Natick quadrangle. The first of these is characterized as a "northeast-trending fault, [that] extends into the. Border [or Northern Boundary] fault and separates pre-Carboniferous from Carboniferous rocks." The second is described as "an east-trending fault [that] extends across the northern part of the [Natick] quadrangle" and also "shows up as a distinct lineament on aeromagnetic maps of both the Natick quadrangle and the adjoining Framingham quadrangle. ${ }^{*} * *$ In the Newton quadrangle this fault divides pre-Carboniferous from Carboniferous rocks and merges here with the northeast-trending Border [or Northern Boundary] fault." The western part of Nelson's east-trending fault is conceivably coincident with what we interpret as the Lake Char fault. However, we are unable to identify the aeromagnetic lineament that he associates with this fault, and Nelson's extension of this feature into the Newton quadrangle puts it athwart the trace of the Lake Char fault as shown on plate $\mathbf{l}$. It is very unlikely, in any case, that the Lake Char fault extends eastward into or merges with the Northern Boundary fault, for this would demand either: (1) That it transect a very steep, well defined magnetic gradient in the southeast corner of the Concord quadrangle (U.S. Geological Survey, 1970c); or (2) that it turn sharply southeastward and nearly perpendicular to its prevailing trend along the northern edge of the Natick quadrangle, thereby isolating rocks mapped with the Westboro Quartzite well north of its trace (pl. 1).

Dips on the Lake Char fault are believed to be generally westerly to northwesterly. We infer from measurements on the associated mylonites that they range from as low as about $25^{\circ}$ near the Connecticut border to $45^{\circ}-50^{\circ}$ as the fault is traced northeastward into Massachusetts (pl. 1). The only magnetically determined dip on the Lake Char fault suggests that it may steepen to $60^{\circ}$ or more where it extends into and eastward beyond the Marlboro quadrangle (pl. 1).

\section{UNNAMED LESSER DISLOCATIONS}

A number of relatively minor dislocations associated in space with the Burlington fault system are inferred from aeromagnetic data, lithologic fabric, and other geologic evidence. Several of these ultimately may be shown to be major breaks in their own right; only one, however, is easily traced into one or the other of the two major faults now included with the Burlington fault system. 
The inferred fault between the Marlboro (Quinebaug equivalent) and Nashoba (lower Tatnic Hill equivalent) Formations in the Oxford quadrangle (pl. 1) coincides with a well-defined and persistent magnetic boundary (U.S. Geological Survey, 1971e). Our interpretation of this contact as a fault is supported by the abrupt northward attenuation of the Nashoba Formation and the occurrence of mylonitic rocks along the extension of this same contact southward into Connecticut. It is unlikely that this fault connects with either the Essex(?) or Clinton(?) faults, rather than turning northward and merging with or terminating against the Lake Char fault; a connection of this sort would place this inferred fault athwart a conspicuous magnetic lineament that is itself truncated against the Lake Char fault (pl. 1).

The fault shown as trending northeastward almost precisely through the junction between the Marlboro and Maynard quadrangles (pl. 1), is also inferred largely from aeromagnetic data. This fault, which probably extends at least $30 \mathrm{~km}$, is identified with a sharp break in magnetic intensity and the truncation of several magnetic lineaments along both sides of its postulated trace (U.S. Geological Survey, 1969a; 1969b; 1969e; $1970 \mathrm{e} ; 1970 \mathrm{i})$. The existence of a fault in about this position is suggested as well by the occurrence of mylonitic fabrics in the rocks of the Nashoba Formation and the subalkaline intrusive series that crop out along the north side of its inferred trace (pl. 1). The mylonitic and blastomylonitic rocks recognized near the eastern edge of the Shrewsbury quadrangle ( $\mathrm{pl}$. 1), for example, form a sharp ridge that roughly parallels this fault about $1 \mathrm{~km}$ northwest of its magnetically determined position. An east-west connection of this fault with the Bloody Bluff(?) fault through the northern Marlboro and Framingham quadrangles is tentatively rejected, since it would demand that the connecting fault drive through one or the other of two magnetic lineaments mapped in the Marlboro quadrangle (U.S. Geological Survey, 1969b).

Recognition of the short but locally well defined fault shown as trending roughly east-west along the northern edge of the Westboro quartzite in the Reading quadrangle (pl. 1), derives chiefly from geologic evidence (Castle, 1964, p. 526-527, pl. 1, fig. 22). The location of this fault has been modified here (pl. 1) on the basis of the detailed aeromagnetic map of the Reading quadrangle (U.S. Geological Survey, 1970m), partly as recontoured by ourselves. Although the position of this fault corresponds geologically to the Lake Char fault as mapped to the southwest (pl. 1), we see no clear geologic or geophysical basis for connecting these two faults through the geologically complex Lexington quadrangle.

The mylonite zones recognized northwest of the Bloody Bluff fault in the Concord and Hudson quadrangles (pl. 1), are apparently unassociated with discretely defined faults. Although the inclusion of these mylonitic rocks with the Burlington fault system is conjectural, our representation of the distribution of these zones is minimal, and many of them 
undoubtedly will be extended and broadened with continuing study of this area.

\section{THE NORTHERN BOUNDARY FAULT OF THE BOSTON BASIN}

The Northern Boundary fault separates the Carboniferous rocks of the Boston basin from an older, largely crystalline terrane to the north and northwest (pl. 1). Recognition of this contact as a fault is attributed by $\mathbf{M}$. P. Billings (1972, written commun.) to W. M. Davis in about 1885. Davis apparently discovered overturned Carboniferous strata immediately south of the Northern Boundary fault and concluded that it probably was a thrust (Billings, 1929, p. 112-113; 1972, written commun.), an interpretation since supported by both Billings (1929, p. 107, 112-113) and LaForge (1932, p. 63, pl. 1). Although Billings (1929, p. 107) initially identified this feature as the "Northern Border fault," Billings and Rahm (1966) subsequently labeled it the "Northern Boundary fault," a usage to which we adhere in this report.

The existence of the Northern Boundary fault was confirmed explicitly in exposures revealed during construction of the Malden Tunnel in the central section of the Boston North quadrangle, which showed the Lynn Volcanic Complex thrust southward over the Cambridge Slate (Billings and Rahm, 1966). The occurrence of this fault is convincingly demonstrated even in the absence of subsurface control. A conspicuous topographic scarp in the Lexington and western half of the Boston North quadrangles coincides with the contact separating the only slightly metamorphosed Cambridge Slate from the highly deformed, precarboniferous crystalline terrane and Lynn Volcanic Complex on the north (LaForge, 1932, pl. 1); because 300-1600 m (Billings, 1929, p. 100-108) of the Carboniferous sequence apparently is missing at this contact, it is unlikely that this contact is an unconformity, at least along its northern and eastern reaches.

The location of the Northern Boundary fault east of long $71^{\circ} 15^{\prime} \mathrm{W}$. (LaForge, 1932, pl. 1) coincides closely with an associated magnetic boundary. Although this contact is poorly defined by the 100-gamma contour compilation shown on plate 1 , it is easily identified on the 20 gamma maps of the Newton, Lexington, Boston North and Lynn quadrangles (U.S. Geological Survey, 1969d; 1970g; 1970a; 1970h), where it is generally less than $100 \mathrm{~m}$ north of the geologically determined position of the fault. Extension of the fault eastward from the central part of the Boston North quadrangle is based on interpretation of the aeromagnetic data. The Northern Boundary fault characteristically separates magnetic terrane of moderate relief on the north from terrane of low relief in the basin, and on this basis it has been traced eastward along the course shown on plate 1. This geophysical projection, moreover, coincides closely with Billings' (1929, p. 100-101) location of this fault more than 40 years ago. 
According to A. E. Nelson (U.S. Geological Survey, 1970p, p. A19), the Northern Boundary fault separates pre-Carboniferous from Carboniferous rocks along a southwest-trending extension into the Natick quadrangle. It is not certain, however, that this contact persists as a fault across the entire quadrangle. Because the corresponding magnetic boundary (U.S. Geological Survey, 1969c) disappears southwestward across the Natick quadrangle, suggesting structural continuity in the preCarboniferous basement rocks, we treat this contact as a normal sedimentary feature beyond its disappearance as a recognizable magnetic boundary.

The inclination of the Northern Boundary fault has been measured at only one place, in the Malden Tunnel, where it is reported as $55^{\circ}$ north (pl. 1). The significance of this measured dip is challenged, however, by Billings and Rahm (1966, p. 122, 132-133) who show that the fault must flatten markedly immediately north of the point of measurement.

\section{OTHER FAULTS}

In addition to the three major faults or fault systems described in the preceding sections, several other faults have now been recognized or inferred within the area of plate 1 . Most of these seemingly less significant breaks are characterized by relatively minor separations; a few, however, may have thousands of metres of displacement. Where modern mapping is available, these additional dislocations have been identified chiefly on the basis of geologic criteria; elsewhere we have relied largely on aeromagnetic data. Relative ease of recognition probably has permitted the identification of a disproportionately large number of cross faults, as contrasted with those parallel to the structural grain. The Burlington mylonite zone, for example, could contain a number of discrete faults, yet in the absence of conspicuous structural discordance it would probably be very difficult to prove their existence.

The fault that defines the northern boundary of the Newbury Formation in the Newburyport East and Newburyport West quadrangles (pl. 1) is taken from Shride (1971, p. 108). Shride (1971) did not discuss the criteria that permitted recognition of this fault. Nevertheless, because the intrusive-metamorphic complex north of the Newbury Formation predates the Newbury, the Newbury Formation must lie either unconformably upon or faulted against these rocks. The relatively straight contact between the Newbury Formation and the adjacent intrusivemetamorphic complex (pl. 1) supports Shride's interpretation of this boundary as a fault; the aeromagnetic data (U.S. Geological Survey, $1970 \mathrm{j}$; 1970k), moreover, are consistent with such an interpretation. Projection of the offset position of this fault southwestward into the adjacent Georgetown quadrangle is based on: (1) The assumption that the northern boundary of the Newbury Formation is defined by a fault along 
its full length; (2) the map distribution of the Newbury Formation as given by Emerson (1917, pl, l) and Clapp (1921, pl. 1); and (3) interpretation of the aeromagnetic map of the Georgetown quadrangle (U.S. Geological Survey, 1970d).

The fault that generally defines the southern boundary of the Newbury Formation is similarly recognized and delineated, and its identification is based on sources and criteria similar to those that permitted definition of the corresponding fault on the north.

The north-trending crossfault along the western margin of the Concord quadrangle (pl. 1) has been modified from Cuppels (1964, p. 83), and is indicated by both geologic and geophysical evidence. Mapped units projecting in toward the trace of the fault show conspicuous, right-lateral separations or, at the very least, sharp bends along this line (Emerson, 1917, pl. X; Cuppels, 1964, p. 83). Similarly, in the adjoining Billerica quadrangle this fault abruptly terminates the westward projection of both the Brimfield-type schist and a broad band of amphibolite recognized along the southern flank of the Nashoba Formation (Castle, 1964, p. 522-523, fig. 22). The aeromagnetic data ( $\mathrm{pl} . \mathrm{l}$ ) are equally persuasive in the sense that conspicuous magnetic lineaments are offset, again right laterally, along this fault trace.

The Pine Hill fault was named by Grew (1970, p. 215, 221-222, pl. 1) for its occurrence near Pine Hill in the northeast corner of the Worcester North quadrangle (pl. 1). In its type area this fault marks an abrupt change in metamorphic grade and partial or complete elimination of section at various places along its mapped trace. The Pine Hill fault is almost certainly continuous with an unnamed fault extending from the western edge of the Clinton quadrangle north-northeastward into New Hampshire (Novotny, 1961). According to Novotny (1961), this fault is indicated by structural discordance between the Oakdale Quartzite (Merrimack Group equivalent) and the Worcester Phyllite, zones of silicified and brecciated rock along the trace, sulfide mineralization, and an apparently abrupt truncation of the chiastolite isograd. Because both this fault segment and the Pine Hill fault as mapped by Grew define the. boundary between the Merrimack Group and the Worcester Phyllite over much of their respective lengths, we have plotted the unmapped segment of the Pine Hill fault in the Sterling quadrangle along this same contact (Emerson, 1917, pl. X).

The Pine Hill fault forms the southwestern segment of Rodgers' (1970, p. 107, pl. 1 (B)) Flint Hill fault, which connects the unnamed fault of Novotny (1961) with the Flint Hill silicified zone mapped by Freedman (1950, p. 479-480, pl. 1) in the Mt. Pawtuckaway quadrangle in southeastern New Hampshire. Rodgers (1970, p. 128, pl. 1 (B)) has tentatively extended the Flint Hill northeastward beyond the Mt. Pawtuckaway quadrangle into the Casco Bay area of southwestern Maine, for a total length of about $225 \mathrm{~km}$. Connection of the several segments comprising 
Rodgers' (1970, pl. I (B)) Flint Hill fault has not as yet, however, been fully demonstrated. For example, the unnamed fault of Novotny (1961) trends generally north-northeastward along a line that projects at least 15 $\mathrm{km}$ west of the main trace of the Flint Hill silicified zone, which Freedman (1950, pl. 1) shows as turning sharply westward and ending in the southwestern part of the Mt. Pawtuckaway quadrangle. Furthermore, although Sriramadas (1966, p. 42-43, pl. 1) recognized several unconnected silicified zones in the Manchester quadrangle (immediately southwest of the Mt. Pawtuckaway quadrangle) that coincide roughly with the position of Rodgers' (1970, pl. 1 (B)) Flint Hill fault, he showed no throughgoing fault anywhere within the Manchester quadrangle, nor did he associate these silicified zones with a sharp drop in metamorphic grade on the southeast side that Rodgers (1970, p. 107) identified elsewhere along the Flint Hill. Accordingly, even though the Pine Hill and Flint Hill faults may belong to the same general system, it is uncertain that they form a single, continuous strand; hence we retain the local name Pine Hill for this fault (pl. 1).

Several faults mapped or inferred athwart the MassachusettsConnecticut boundary derive chiefly from projection northward of recognized occurrences south of the Webster quadrangle and from interpretation of the aeromagnetic data. Thus, the Eastford fault in Connecticut coincides with the northeastward trending contact between the Hebron Formation (Merrimack Group) and the Paxton Quartz Schist (Pease and Peper, 1968, p. (F-2)2); its projection into Massachusetts (pl. l) is approximately coincident with a similarly positioned fault mapped by Emerson (1917, Pl. X). The inferred fault shown as separating the Merrimack Group from the Ayer Granite at the state line (pl. l) is associated with cataclastic fabrics developed within the Ayer; we have no evidence, however, to suggest that it extends more than a kilometre or two into Massachusetts.

\section{DEVELOPMENT OF THE EASTERN MASSACHUSETTS STRUCTURAL DISLOCATIONS}

The dislocations within the structural belt shown on plate 1 have been characterized by a long and complex history; this generalization is very nearly the only unqualified statement that can be made regarding the evolution of these features. Most of the uncertainty surrounding the development of these dislocations is ultimately traceable to corresponding uncertainties in both the absolute and relative ages of the involved rocks.

\section{KINEMATICS}

We have deliberately refrained from any prior discussion of kinematics, chiefly because there is so little reliable information on which to base such a discussion. Because the faults and other dislc zations we describe here are 
so obscurely expressed, the movements that accompanied their evolution are very poorly understood.

Some evidence suggests that early in the evolution of the mylonitic zones the northwesterly blocks may have moved to the south and east. Scattered measurements of what we interpret as "a" lineations within the Burlington mylonite zone (Castle, 1964, pl. 1, fig. 22), for example, indicate movements at generally right angles to the structural grain. However, although these observations are consistent with those of Dixon and Lundgren (1968, p. 226), who suggest that " $a$ " lineations associated with the Lake Char cataclasites indicate east-southeastward movement of the upper plate, Lundgren (1972, written commun.) has since concluded that many of these so-called "a" lineations coincide with or closely parallel fold hinges; the " $a$ " lineations identified with the Burlington mylonite belt may be equally equivocal indices of movement direction.

Folding of the Burlington mylonites (and perhaps others as well) probably began before mylonitization ceased, for, as suggested particularly by the magnetic patterns (pl. 1), folded mylonitic rocks project into and against zones of thinly laminated mylonite that lie within and commonly bound the Burlington belt. Moreover, " $b$ " lineations defined by both major and minor fold axes within the mylonite belt show shallow plunges (Castle, 1964, p. 517-519, pl. 1, fig. 22), which suggest that the northwest-southeast movement tentatively identified with the earlier mylonitization continued into the later stages of cataclasis. The amount of displacement associated with the mylonitization remains unknown; it could conceivably range from almost zero to thousands of metres.

The sense(s) of movement and the magnitudes of the displacements on the apparently discrete faults shown on plate 1 are little better known than are the movements and displacements that accompanied the mylonitization. The generally shallow plunges of adjacent folds interpreted as drag phenomena argue for chiefly dip-slip motions on at least the major faults (Castle, 1964, p. 499-520, pl. 1, fig. 22). Skehan (1968, p. 287, 290), moreover, concludes from examination of continuous exposure in that part of the Wachusett-Marlborough Tunnel in the Clinton quadrangle, that "data from slickensides, from folds developed by faulting, and from related movement-direction indicators suggest that the average tectonic transport direction on westerly dipping reverse faults [in the Clinton area] is easterly." Nevertheless, locally steep (greater than $45^{\circ}$ ) fold axes adjacent to the Essex fault in the South Groveland and Hudson quadrangles (Castle, 1964, pl. 1, fig. 22; Hansen, 1956, pl. 1) suggest a component of southerly or even southwesterly movement of the northern block. Furthermore, the relatively straight traces of several faults, coupled with apparently steep dips, are inconsistent with major thrusting. The steep dips may be due to demonstrably later folding (see also, Dixon and Lundgren, 1968, p. 229), but the other apparently strike-slip features 
associated with these faults are much less readily explained in the absence of transcurrent movement.

Little is known of the cumulative displacements associated with the discrete faulting, and we can suggest no more than minimal separations; net slip has not been measured on any of the faults shown on plate 1 . According to Grew (1970, p. 222) an estimated 1100-1200 m of section is missing along parts of the Pine Hill fault, and an even greater separation is indicated for at least one other fault in the Worcester area (Grew, 1970, p. 222). The fact that separations of this magnitude can be demonstrated locally for these faults argues that faults such as the Essex and the Lake Char, which are characterized by sharply contrasting lithologies and otherwise questionably related formations across their traces, probably sustained movements of many thousands of metres. Yet, as Dixon and Lundgren (1968, p. 226-227) have observed in connection with the Honey Hill and Lake Char faults, the amount of movement on any of these faults is very difficult to estimate, and in many cases no displacements can be proven.

It is tempting to conclude that the eastern Massachusetts-eastern Connecticut dislocation system (comprising the Honey Hill, Lake Char, Bloody Bluff, Essex, and related faults, together with the Burlington mylonite zone) must be of fundamental, even global, structural significance, simply on the basis of its greater than $200 \mathrm{~km}$ length (fig. 2). This conclusion is certainly supported, for example, by the conspicuously contrasting nature of many adjoining fault blocks, and by the approximate coincidence between this fault system and the striking discontinuity in age between the White Mountain Plutonic Series of northern New England and the petrologically similar but vastly older "alkalic" intrusive series of Massachusetts and Rhode Island (Castle, 1964, p. 529). The inferences of Skehan (1967, p. 240) and Bell (1968, U.S. Geological Survey, 1969f, p. A21-A22) seem to further support this notion of great structural significance. Thus, Skehan states that "displacement [along the Essex fault] must be of the order of at least tens of miles [or kilometres]." Similarly, according to Bell, "much of eastern Massachusetts is part of a great thrust fault zone at least 40 miles [65 km] wide. *** The major faults are northeast-trending strike-slip faults having displacements of many miles" (U.S. Geological Survey, 1969f, p. A21-A22). A. E. Nelson (U.S. Geological Survey, 1970p, p. A19), moreover, has since concluded from studies in the Natick quadrangle that at least one fault in the Natick area "appears to have a [right-lateral] displacement in excess of 7 miles [11 km]." Unfortunately, neither Skehan, nor Bell, nor Nelson present specific evidence in support of these multi-kilometre displacements, and we are unable to evaluate the full significance of Bell's (1968; U.S. Geological Survey, 1969f, p. A21-A22) postulated transcurrentthrust system. 
In spite of several suggestive features and published assertions of large displacements, the available evidence is inconsistent with great displacements on any of the eastern Massachusetts faults, or even on the system as a whole. Thus, the correlation of identifiable units across the Essex and Clinton faults in the Worcester area certainly diminishes the likelihood that these faults have sustained great displacements or are of otherwise great structural significance. Similarly, the likely correlation of the Marlboro (Boxford equivalent) Formation in the South Groveland quadrangle with the Rye Formation in southeastern New Hampshire (Castle, 1965b, p. C84-C85), on the opposite side of the Essex fault, argues equally forcefully against very large displacements on this fault. The most compelling evidence against such significance, however, is the apparent termination of the southwesterly projection of the Honey Hill fault in the Deep River quadrangle in Connecticut (Dixon and Lundgren, 1968, p. 222). Accordingly, it seems much more likely that the eastern Massachusetts dislocation system is simply one expression of possibly several stages of subductional deformation, overprinted in part by later block faulting. Hence we are inclined to extend the conclusions of Lundgren and Ebblin (1972), who view the Honey Hill fault as an intensely strained zone of cataclastic rocks, but hardly of global significance, and probably of no more importance than dozens of other Appalachian dislocations.

\section{TEMPORAL EVOLUTION}

The earliest differential movements within the eastern Massachusetts dislocation belt are recorded by mylonitic rocks-specifically, those of the Burlington mylonite zone (pl. 1). Because the Burlington mylonite zone is invaded by virtually undeformed rocks of the "alkalic" intrusive series (Castle, 1964, pl. 1), we conclude that the Burlington mylonitization began before the Late Ordovician (Zartman and Marvin, 1971) intrusion of these rocks.

The maximum likely age of mylonitization is much more difficult to determine. The Boston Platform (comprising roughly that part of New England south and east of the Essex and Lake Char faults), which is correlated with the Avalon, Cape Breton, and St. John Platforms in the eastern Maritime provinces largely on the basis of Atlantic-type Cambrian faunal assemblages, is identified by Bird and Dewey (1970, p. 1033-1034) with Precambrian, apparently contractional deformation. Insofar as we are aware, direct evidence in support of this conclusion is unavailable in the Boston area. Nevertheless, early Hadrynian (Precambrian) formations in eastern Newfoundland, southern New Brunswick, and especially Cape Breton Island, consist of rock assemblages similar to those recognized among the metasedimentary and metavolcanic units within the structural belt shown on plate 1 (Poole and others, 1970 , p. 230, 232). Because these early Hadrynian rocks reportedly 
were mildly deformed during the late Precambrian Avalonian orogeny (Poole and others, 1970, p. 232-233), it is not unlikely that the lithologically similar and similarly positioned rocks of the Boston Platform were also deformed during Avalonian orogenesis. This likelihood is supported by the recent recognition of Avalonian(?) deformation between 620 m.y. and 570 m.y. ago in the central Piedmont of Virginia and North Carolina (Glover and others, 1971).

The problem may also be approached by means of local, yet still indirect evidence. Zartman and Naylor (1972) have assigned a Precambrian (600-650 m.y.) age to the Dedham Granodiorite, Milford Granite, Northbridge Granite Gneiss, and "some plutonic rocks from north of Boston" on the basis of U-Th- $\mathrm{Pb}$ zircon isotopic ages and other radiometric data. (See also, Moorbath and others, 1962, p. 7; Ramo and Fairbairn, 1963, p. 53; and Fairbairn and others, 1967.) These Precambrian ages, moreover, are consistent with the occurrence of fossiliferous Cambrian strata unconformably overlying Dedham Granodiorite at Hoppin Hill (Dowse, 1950). Because the Burlington mylonitization involved tonalitic and dioritic rocks identical with those mapped with the subalkaline(?) rocks along the southern flank of the Burlington belt (pl. 1), and because these rocks probably are coeval with hornblende diorite from the northeastern part of the Georgetown quadrangle, from which a K-Ar hornblende date of $646 \pm 21 \mathrm{~m}$.y. has been obtained (R. E. Zartman, 1972, oral commun.), mylonitization probably could not have begun earlier than late Precambrian time. Mylonitization almost certainly began when these rocks were still under at least slightly elevated $P \cdot T$ conditions. (See Dixon and Lundgren, 1968, p. 228-229; Higgins, 1971, p. 65-67.) Accordingly, because evidence of thermal events in this area during the late Precambrian-Late Ordovician interval is lacking, and because Cambrian faunal assemblages within and adjacent to the Boston basin (LaForge, 1932, p. 18-21, pl. 1) suggest quiescent conditions during Cambrian time, it is likely that the Burlington mylonitization began during the late Precambrian. This conclusion is challenged chiefly by the involvement of apparently Ordovician or younger plutonic rocks in cataclastic zones recognized in eastern Connecticut (Snyder, 1964, p. I18-I19, pl. 1; Zartman and others, 1965; Dixon and Lundgren, 1968, p. 228-229). It is possible, of course, that the generation of mylonitic rocks in Connecticut began later or continued longer than it did in Massachusetts; alternatively, the Burlington mylonitization may be much younger than late Precambrian (or the primary age of the radiometrically dated plutonic unit in eastern Connecticut may be much older than Ordovician).

Whether or not differential movements persisted intermittently within the eastern Massachusetts dislocation belt during early and middle Paleozoic time is unknown. We can state with reasonable certainty only that some of the discrete faulting postdated Early Devonian time (speci- 
fically, that isolating the Newbury Formation), and that other faulting occurred during or after Carboniferous time (specifically, that along the Northern Boundary fault and the Clinton fault or one of its southern branches). (See also, LaForge, 1932, pl. 1; Grew and others, 1970, p. 122-124.) Grew, Mamay, and Barghoorn (1970, p. 124) cite evidence suggesting that much of this faulting may have been somewhat younger than or eonceivably associated with Alleghenyan orogeny during Permian time. Such faulting, moreover, is certainly consistent with the 239-329 m.y. K-Ar mica ("Permian disturbance") dates reported from along the dislocation belt (Zartman and others, 1970, p. 3360-3361, 3367-3368).

We have no direct evidence of Acadian (Early and Middle Devonian) movement on any of these faults. Faulting along the edge of the Newbury Formation (pl. 1) clearly was post-Early Devonian, but could just as easily have been Carboniferous, Permian, or even Triassic. Locally altered but otherwise undeformed Triassic(?) dikes concentrated along the Burlington mylonite belt, adjacent to the Essex fault (Castle, 1964, p. 487-489, pl. 1), and athwart the Northern Boundary fault (LaForge, 1932, pl. 1) argue, however, that movement on these faults had largely ceased by Triassic time.

There exisis equivocal evidence of post-Precambrian, preCarboniferous faulting within the area of plate 1. Thus, the poorly defined fault along the northern boundary of the Westboro Quartzite in the southern part of the Reading quadrangle is apparently cut by Late Ordovician "alkalic" rocks, yet truncates the adjacent mylonites. Although late Precambrian displacements cannot be categorically denied, this relatively discrete faulting could have been Ordovician. Movemerits on the Bloody Bluff fault (and perhaps the Lake Char as well) are also reasonably associated with this postulated pre-Late Ordovician faulting of the Westboro Quartzite; these movements followed the folding of the main mylonite belt and formed the thinly laminated mylonites along the trace of the Bloody Bluff. Similarly, mylonitic parts of both the Ayer Granite and the subalkaline intrusive series cropping out along the main trace of the Essex fault (pl. 1) are concentrated against the fault, yet they are apparently discontinuous and cut out locally. such that the earliest movements along the Essex fault, now expressed by mylonites identified with deep-seated deformation, probably preceded Carboniferous or later faulting. The mylonitic character of these rocks indicates that this early episode may have closely followed the Ordovician intrusion of the Ayer Granite and Newburyport Quartz Diorite (Zartman and Naylor, 1972).

\section{CONCLUSION}

A broad and obviously complex northeast-trending dislocation belt slices diagonally across eastern Massachusetts. Northwest of the Northern Boundary fault this belt consists of two major strands-the Essex and the 
Burlington fault systems-neither of which was recognized prior to the middle 1950's. The general obscurity of these features, to which their latter-day recognition clearly testifies, explains in part why the structural history of this area remains so poorly understood. Accumulated evidence now suggests only that the evolution of the dislocations shown on plate 1 may have spanned nearly all of Paleozoic.time and part of Precambrian time as well. Additional carefully formulated field studies alone probably will not resolve the problems introduced with the recognition of the eastern Massachusetts dislocation belt. Not only are the outcrops extremely sparse over much of this area, but both the relative and absolute (geologic) ages of the involved rocks are known only in a general way. Systematic isotopic age investigations across the regional strike, coupled with ground magnetic studies in selected critical areas, could lead to a much more explicit definition of the individual faults and a vastly improved understanding of their evolution in time.

\section{ACKNOWLEDGMENTS}

We thank Priestley Toulmin, III, for petrographic interpretation of rocks collected from the Salem quadrangle. R. E. Zartman has permitted use of a previously unpublished K-Ar isotopic date obtained from a diorite north of Boston. We are especially indebted to Prof. M. P. Billings, Prof. L. W. Lundgren, G. P. Eaton, and W. R. Hansen for thoughtful reviews of an earlier version of the manuscript.

\section{REFERENCES CITED}

Bell, K. G., 1968, Faults in eastern Massachusetts in Abstracts for 1967 [abs.]: Geol. Soc. America Special Paper 115, p. 250.

Billings, M. P., 1929, Structural geology of the eastern part of the Boston basin: Am. Jour. Sci., v. 218, p. 97-137.

1956, The geology of New Hampshire; Part II-Bedrock geology: Concord, N.H., New Hampshire State Planning and Development Commission, 203 p.

Billings, M. P., and Rahm, D. A., 1966, Geology of the Malden Tunnel, Massachusetts: Jour. Boston Soc. Civil Engineers, v. 53, p. 116-141.

Bird, J. M., and Dewey, J. F., 1970, Lithosphere plate-continental margin tectonics and the evolution of the Appalachian Orogen: Geol. Soc. America Bull., v. 81, p. 1031-1060.

Boucot, A. J., 1968, Silurian and Devonian of the northern Appalachians in Studies of Appalachian geology, northern and Maritime (E-an Zen and others, eds.): New York, Interscience Publishers, p. 83-94.

Carter, N. L., Christie, J. M., and Griggs, D. T., 1964, Experimental deformation and recrystallization of quartz: Jour. Geology, v. 72, p. 687-733.

Castle, R. O., 1964, Geology of the Andover Granite and surrounding rocks, Massachusetts: U.S. Geol. Survey open-file rept., 550 p., 50 pl., 30 figs., 28 tables.

1965a, A proposed revision of the subalkaline intrusive series of northeastern Massachusetts in Geological Survey Research 1965: U.S. Geol. Survey Prof. Paper 525-C, p. C74-C80.

1965b, Gneissic rocks in the South Groveland quadrangle, Essex County, Massachusetts in Geological Survey Research 1965: U.S. Geol. Survey Prof. Paper 525-C, p. C81-C86. 
1966, Major structural discontinuities across southeastern New England: New evidence in Abstracts for 1965 [abs.]: Geol. Soc. America Special Paper 87, p. 197-198.

Christie, J. M., 1963, The Moine thrust zone in the Assynt region, northwest Scotland: California Univ. Pubs. Geol. Sci., v. 40, p. 345-440.

Clapp, C. H., 1921, Geology of the igneous rocks of Essex County, Massachusetts: U.S. Geol. Survey Bull. 704, 132 p.

Crosby, W. O., 1899, Geology of the Wachusett Dam and Wachusett Aqueduct Tunnel of the Metropolitan Water Works in the vicinity of Clinton, Mass.: Technology Quarterly, v. 12, p. 68-96.

Cuppels, N. P., 1961, Post-Carboniferous deformation of metamorphic and igneous rocks near the Northern Boundary fault, Boston Basin, Massachusetts in Geological Survey Research 1961: U.S. Geol. Survey Prof. Paper 424-D, p. D46-D48.

1964, The Marlboro Formation in the Concord quadrangle: Trip F in Guidebook to field trips in the Boston area and vicinity (Skehan, J. W., ed.): New England Intercollegiate Geol. Conf., 56th Ann. Mtg., p. 81-89.

Dixon, H. R., 1964, The Putnam Group of eastern Connecticut: U.S. Geol. Survey Bull. 1194-C, p. Cl-C12.

Dixon, H. R., and Lundgren, L. W., 1968, Structure of eastern Connecticut in Studies of Appalachian geology, northern and Maritime (E-an Zen and others, eds.): New York, Interscience Publishers, p. 219-229.

Dowse, A. N., 1950, New evidence on the Cambrian contact at Hoppin Hill, North Attleboro, Massachusetts: Am. Jour. Sci., v. 248, p. 95-99.

Emerson, B. K., 1917, Geology of Massachusetts and Rhode Island: U.S. Geol. Survey Bull. $597,289 \mathrm{p}$.

Fabiano, E. B., and Peddie, N. W., 1969, 1969 grid values of total magnetic intensity IGRF-1965: ESSA Technical Rept., U.S. Coast and Geodetic Survey 38, 55 p.

Fairbairn, H. W., Moorbath, S., Ramo, A. O., Pinson, W. H., Jr., and Hurley, P. M., 1967, Rb-Sr age of granitic rocks of southeastern Massachusetts and the age of the Lower Cambrian at Hoppin Hill: Earth and Planetary Sci. Letters, v. 2, p. 321-328.

Foye, W. G., 1949, The geology of eastern Connecticut: Connecticut Geol. and Natural History Survey Bull. 74, 100 p.

Freedman, Jacob, 1950, Stratigraphy and structure of the Mt. Pawtuckaway quadrangle, southeastern New Hampshire: Geol. Soc. America Bull., v. 61, p. 449-492.

Glover, Lynn, 3rd, Sinha, A. K., and Higgins, M. W., 1971, Virgilina phase (Precambrian and Early Cambrian(?)) of the Avalonian orogeny in the central Piedmont of Virginia and North Carolina [abs.]: Geol. Soc. America, Abs. with Programs (Ann. Mtg.), v. 3, no. 7, p. 581-582.

Grew, E. S., 1970, Geology of the Pennsylvanian and pre-Pennsylvanian rocks of the Worcester area, Massachusetts: Cambridge, Mass., Harvard Univ., Ph.D. thesis, 263 p.

1973, Stratigraphy of the Pennsylvanian and pre-Pennsylvanian rocks of the Worcester area, Massachusetts: Am. Jour. Sci., v. 273, p. 113-129.

Grew, E. S., Mamay, S. H., and Barghoorn, E. S., 1970, Age of plant fossils from the Worcester coal mine, Worcester, Massachusetts: Am. Jour. Sci., v. 268, p. 113-126.

Handford, L. S., 1965, Rb-Sr whole rock age study of the Andover and Chelmsford Granites, Massachusetts in Variations in isotopic abundances of strontium, calcium, and argon and related topics: U.S. Atomic Energy Comm., 13th Ann. Prog. Rept. for 1965, Massachusetts Inst. Technology-1381-13, Contract AT (30-1)-1381, p. 11-14.

Hansen, W. R., 1956, Geology and mineral resources of the Hudson and Maynard quadrangles, Massachusetts: U.S. Geol. Survey Bull. 1038, 104 p.

Higgins, M. W., 1971, Cataclastic rocks: U.S. Geol. Survey Prof. Paper 687, 97 p.

Hsu, K. J., 1955, Granulites and mylonites of the region about Cucamonga and San Antonio Canyons, San Gabriel Mountains, California: California Univ. Pubs. Geol. Sci., v. 30 , p. 223-352. 
LaForge, Laurence, 1932, Geology of the Boston area, Massachusetts: U.S. Geol. Survey Bull. 839, 105 p.

Lundgren, L. W., Jr., Goldsmith, Richard, and Snyder, G. L., 1958, Major thrust fault in southeastern Connecticut [abs.]: Geol. Soc. America Bull., v. 69, p. 1606.

Lundgren, L. W., and Ebblin, C. P., 1972,. Honey Hill fault in eastern Connecticut: a revised interpretation [abs.]: Geol. Soc. America Abs. with Programs (Northeastern Sec.), v. 4, no. 1, p. 28.

Moorbath, S., and others, 1962, Rb-Sr investigation of the Northbridge Granite-Gneiss, Massachusetts in Variations in isotopic abundances of strontium, calcium, and argon and related topics (Hurley, P. M., and others, eds.): U.S. Atomic Energy Comm., 10th Ann. Prog. Rept. for 1962, Massachusetts Inst. Technology, NYO-3943, Contract AT (30-1)-1381, p. 7-8.

Novotny, R. F., 1961, A regional fault in east-central Massachusetts and southern New Hampshire in Geological Survey Research 1961: U.S. Geol. Survey Prof. Paper 424-D, p. D48-D49.

1969, The geology of the seacoast region, New Hampshire: Concord, N.H., New Hampshire Dept. Resources and Economic Development, 46 p.

Pease, M. H., and Peper, J. D., 1968, The Brimfield(?) and Paxton(?) Formations in northeastern Connecticut: Trip F-5 in Guidebook for field trips in Connecticut (Orville, P. M., ed.): New England Intercollegiate Geol. Conf., 60th Ann. Mtg., p. (F-5) l-(F-5)7.

Poole, W. H., Sanford, B. V., Williams, H., and Kelley, D. G., 1970, Geology of southeastern Canada in Geology and economic minerals of Canada (Douglas, R. J. W., ed.): Geol. Survey Canada, Econ. Geol. Rept. no. 1, p. 227-304.

Ramo, Alan, and Fairbairn, H. W., 1963, Preliminary age study of the Dedham granitic rocks in Variations in isotopic abundances of strontium, calcium, and argon and related topics (Hurley, P. M., and others, eds.): U.S. Atomic Energy Comm., 11th Ann. Prog. Rept. for 1963, Massachusetts Inst. Technology, NYO-10, 518, Contract AT (30-1)-1381, p. 53-54.

Rodgers, John, 1970, The tectonics of the Appalachians: New York, Wiley-Interscience, $271 \mathrm{p}$.

Sclar, C. B., 1950, Origin of a layered ultramylonite from southeastern Connecticut [abs.]: Geol. Soc. America Bull., v. 61, p. 1501.

Shelley, David, 1971, Hypothesis to explain the preferred orientations of quartz and calcite produced during syntectonic recrystallization: Geol. Soc. America Bull., v. 82, p. 1943-1954.

Shride, A. F., 1971, Igneous rocks of the Seabrook, New Hampshire-Newbury, Massachusetts area: Trip B-5 in Guidebook for field trips in central New Hampshire and contiguous areas (Lyons, J. B., and Stewart, G. W., eds.): New England Intercollegiate Geol. Conf., 63rd Ann. Mtg., p. 105-117.

Skehan, J. W., 1967, Geology of the Wachusett-Marlborough Tunnel, east-central Massachusetts: a preliminary report in Economic geology in Massachusetts (Farquhar, O. C., ed.): January 1966 Conf. Proc., Univ. Massachusetts Graduate School, p. 237-244.

1968, Fracture tectonics of southeastern New England as illustrated by the Wachusett-Marlborough Tunnel, east-central Massachusetts in Studies of Appalachian geology, northern and Maritime (E-an Zen and others, eds.): New York, Interscience Publishers, p. 281-290.

Snyder, G. L., 1964, Petrochemistry and bedrock geology of the Fitchville quaarangle, Connecticut: U.S. Geol. Survey Bull. 1161-I, 63 p.

Sriramadas, Aluru, 1966, Geology of the Manchester quadrangle, New Hampshire: Concord, N.H., New Hampshire Dept. Resources and Economic Development, Bull. no. $2,78 \mathrm{p}$. 
Theodore, T. G., 1966, The fabric of a high-grade mylonite zone in southern California [abs.]: Am. Geophys. Union Trans., v. 47, p. 491-492.

Theodore, T. G., 1967, Structure and petrology of the gneisses and mylonites at Coyote Mountain, Borrego Springs, California: California Univ. Los Angeles, Ph.D. thesis, $268 \mathrm{p}$.

Toulmin, Priestley, III, 1964, Bedrock geology of the Salem quadrangle and vicinity, Massachusetts: U.S. Geol. Survey Bull. 1163-A, 79 p.

U.S. Geological Survey, 1968a, Aeromagnetic map of the Webster quadrangle, Worcester County, Massachusetts and Windham County, Connecticut: U.S. Geol. Survey Geophys. Invest., Map GP-634.

1968b, Aeromagnetic map of the Worcester South quadrangle, Worcester County, Massachusetts: U.S. Geol. Survey Geophys. Invest., Map GP-623.

1969a, Aeromagnetic map of the Framingham quadrangle, Middlesex and Worcester Counties, Massachusetts: U.S. Geol. Survey Geophys. Invest., Map GP-674. 1969b, Aeromagnetic map of the Marlboro quadrangle, Middlesex and Worcester Counties, Massachusetts: U.S. Geol. Survey Geophys. Invest., Map GP-673. 1969c, Aeromagnetic map of the Natick quadrangle, Middlesex and Norfolk Counties, Massachusetts: U.S. Geol. Survey Geophys. Invest, Map GP-675.

1969d, Aeromagnetic map of the Newton quadrangle, Middlesex, Norfolk, and Suffolk Counties, Massachusetts: U.S. Geol. Survey Geophys. Invest., Map GP-676. $1969 \mathrm{e}$, Aeromagnetic map of the Shrewsbury quadrangle, Worcester County, Massachusetts: U.S. Geol. Survey Geophys. Invest., Map GP-672.

1969f, Geological Survey Research 1969: U.S. Geol. Survey Prof. Paper 650-A, $425 \mathrm{p}$.

1970a, Aeromagnetic map of the Boston North quadrangle, Middlesex, Suffolk, and Essex Counties, Massachusetts: U.S. Geol. Survey Geophys. Invest., Map GP-708. $1970 \mathrm{~b}$, Aeromagnetic map of the Clinton quadrangle, Worcester County, Massachusetts: U.S. Geol. Survey Geophys. Invest., Map GP-703.

1970c, Aeromagnetic map of the Concord quadrangle, Middlesex County, Massachusetts: U.S. Geol. Survey Geophys. Invest., Map GP-706.

1970 d, Aeromagnetic map of the Georgetown quadrangle, Essex County, Massachusetts: U.S. Geol. Survey Geophys. Invest., Map GP-718.

1970e, Aeromagnetic map of the Hudson quadrangle, Worcester and Middlesex Counties, Massachusetts: U.S. Geol. Survey Geophys. Invest., Map GP-704.

1970f, Aeromagnetic map of the Lawrence quadrangle, Essex and Middlesex Counties, Massachusetts, and Rockingham and Hillsborough Counties, New Hampshire: U.S. Geol. Survey Geophys. Invest., Map GP-716.

$1970 \mathrm{~g}$, Aeromagnetic map of the Lexington quadrangle, Middlesex County, Massachusetts: U.S. Geol. Survey Geophys. Invest., Map GP-707.

1970h, Aeromagnetic map of the Lynn quadrangle, Essex and Suffolk Counties,

Massachusetts: U.S. Geol. Survey Geophys. Invest., Map GP-709.

1970i, Aeromagnetic map of the Maynard quadrangle, Middlesex County, Massa-

chusetts: U.S. Geol. Survey Geophys. Invest., Map GP-705.

1970 j, Aeromagnetic map of the Newburyport East quadrangle, Essex County,

Massachusetts, and Rockingham County, New Hampshire: U.S. Geol. Survey

Geophys. Invest., Map GP-715.

$1970 \mathrm{k}$, Aeromagnetic map of the Newburyport West quadrangle, Essex County,

Massachusetts, and Rockingham County, New Hampshire: U.S. Geol. Survey

Geophys. Invest., Map GP-714.

19701, Aeromagnetic map of part of the Ipswich quadrangle, Essex County, Massa-

chusetts: U.S. Geol. Survey Geophys. Invest., Map GP-719.

$1970 \mathrm{~m}$, Aeromagnetic map of the Reading quadrangle, Middlesex and Essex

Counties, Massachusetts: U.S. Geol. Survey Geophys. Invest., Map GP-721. 
1970n, Aeromagnetic map of the Salem quadrangle, Essex County, Massachusetts:

U.S. Geol. Survey Geophys. Invest., Map GP-722:

1970o, Aeromagnetic map of the Wilmington quadrangle, Middlesex and Essex

Counties, Massachusetts: U.S. Geol. Survey Geophys. Invest., Map GP-720.

1970p, Geological Survey Research 1970: U.S. Geol. Survey Prof. Paper 700-A, $426 \mathrm{p}$.

1971a, Aeromagnetic map of the Ayer quadrangle, Middlesex and Worcester Counties, Massachusetts: U.S. Geol. Survey Geophys. Invest., Map GP-741.

1971b, Aeromagnetic map of the Billerica quadrangle, Middlesex County, Massachusetts: U.S. Geol. Survey Geophys. Invest., Map GP-734.

1971c, Aeromagnetic map of the Grafton quadrangle, Worcester County, Massachusetts: U.S. Geol. Survey Geophys. Invest., Map GP-759.

1971d, Aeromagnetic map of the Lowell quadrangle, Middlesex and Essex Counties, Massachusetts, and Hillsborough County, New Hampshire: U.S. Geol. Survey Geophys. Invest., Map GP-734.

197le, Aeromagnetic map of the Oxford quadrangle, Massachusetts, Connecticut, and Rhode Island: U.S. Geol. Survey Geophys. Invest., Map GP-768.

1971f, Aeromagnetic map of the Westford quadrangle, Middlesex County, Massachusetts: U.S. Geol. Survey Geophys. Invest., Map GP-742.

1971g. Geological Survey Research 1971: U.S. Geol. Survey Prof. Paper 750-A, $418 \mathrm{p}$.

Vacquier, Victor, Steenland, N. C., Henderson, R. G., and Zietz, Isidore, 1951, Interpretation of aeromagnetic maps: Geol. Soc. America Mem. 47, 151 p.

Zartman, R. E., Hurley, P. M., Krueger, H. W., and Giletti, B. J., 1970, A Permian disturbance of K-Ar radiometric ages in New England-its occurrence and cause: Geol. Soc. America Bull., v. 81, p. 3359-3373.

Zartman, R. E., and Marvin, R. F., 1971, Radiometric age (Late Ordovician) of the Quincy, Cape Ann, and Peabody Granites from eastern Massachusetts: Geol. Soc. America Bull., v. 82, p. 937-958.

Zartman, R. E., and Naylor, R. S., 1972, Structural implications of some U-Th-Pb zircon isotopic ages of igneous rocks in eastern Massachusetts [abs.]: Geol. Soc. America, Abs. with Programs (Northeastern Sec.), v. 4, no. 1, p. 54-55.

Zartman, R. E., Snyder, G. W., Stern, T. W., Marvin, R. F., and Bucknam, R. C., 1965, Implications of new radiometric ages in eastern Connecticut and Massachusetts in Geological Survey Research 1965: U.S. Geol. Survey Prof. Paper 525-D, p. DI-D10. 